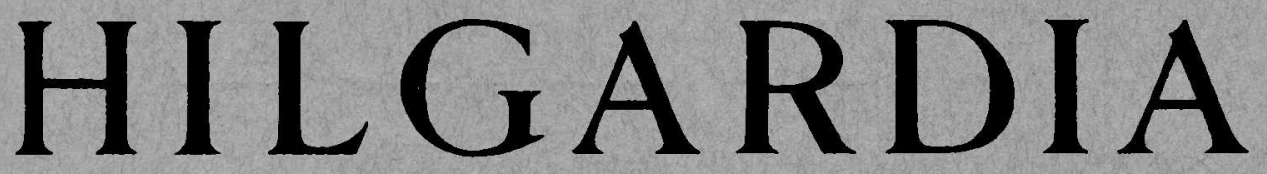

A Journal of Agricultural Science Published by the California Agricultural Experiment Station

\title{
VOLUME 19 \\ MARCH, 1950 \\ ANALYSIS OF ORANGE LEAVES FOR DIAGNOSING \\ NUTRIENT STATUS WITH REFERENCE TO POTASSIUM
}

NUMBER 17

H. D. CHAPMAN and S. M. BROWN

UNIVERSITY OF CALIFORNIA · BERKELEY, CALIFORNIA 
This paper reports a detailed investigation carried out to determine whether the potassium status of a citrus tree can be determined by leaf analysis. The study has shown that the leaf, of the various plant parts tested, best reflects the varying potassium condition of the nutrient medium. A set of standards based on controlled culture and field $e x$ periments has been worked out for three- to sevenmonth-old spring-cycle leaves, and is thought to reliably indicate the current potassium status of the tree. Detailed directions for sampling, analysis, and interpretation are given. 


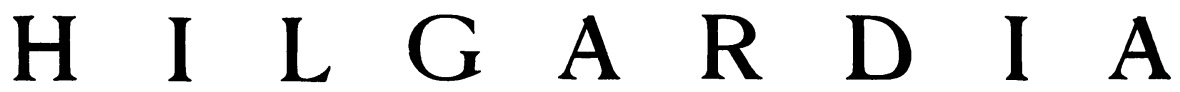

A Journal of Agricultural Science Published by

the California Agricultural Experiment Station

VOL. 19

MARCH, 1950

No. 17

\section{ANALYSIS OF ORANGE LEAVES FOR DIAGNOSING NUTRIENT STATUS WITH REFERENCE TO POTASSIUM ${ }^{1,2}$}

\author{
H. D. CHAPMAN ${ }^{3}$ and S. M. BROWN
}

\section{INTRODUCTION}

A major objective in our nutritional work with citrus has been to develop criteria and methods by which to evaluate the nutritional status of the tree, thus providing more accurate guidance for fertilizer practice.

The acute stages of mineral element deficiencies and excesses in citrus are sufficiently tangible and specific (Camp, Chapman, Bahrt and Parker, 1941; Chapman and Kelley, 1943; Chapman, 1946) ${ }^{5}$ to enable a positive diagnosis in most cases. But the early or incipient stages are in general not characterized by any identifiable growth, fruit, leaf or other symptoms. These early or incipient stages are, however, the conditions most frequently encountered in the field. The need for supplementary tests is therefore apparent.

Investigators working with trees as well as other crops have come to feel that the plant itself offers a more promising means of diagnosing nutrient status and fertilizer requirement than the soil. At the same time it is recognized that any over-all evaluation of tree condition, fertilizer requirement, and recommended soil-management practice will require considerable soil and management information in addition to what is furnished by the plant.

The work reported in this paper was undertaken in an effort to develop techniques for evaluating the potassium status of orange trees. Specific investigations were carried on to establish (1) the part of the plant best suited for assessing potassium status; (2) tentative standards ; (3) limitations of the method and factors to take into account in interpreting results; and (4) proper sampling and analysis techniques.

${ }^{1}$ Received for publication July 7, 1949.

2 Paper no. 616, University of California Citrus Experiment Station, Riverside, California.

${ }^{3}$ Professor of Soils and Plant Nutrition and Chemist in the Experiment Station.

- Associate Chemist in the Experiment Station (deceased).

"See "Literature Cited" for citations, referred to in text by author and date. 


\section{REVIEW OF LITERATURE}

The early as well as the more recent work on the general problem of nutrient status diagnosis by plant analysis has been thoroughly reviewed by Goodall and Gregory (1947). In addition Ulrich (1948) has prepared a valuable chapter on plant analysis in the recent book, Diagnostic Techniques for Soils and Crops. Hence a brief mention of basic principles, and a brief review of such work as has been done by others in citrus will suffice here.

It is well recognized that each plant presents a separate problem in establishing standards, suitable plant parts, etc. Generally accepted too is the idea that plant analysis based upon a single sampling can indicate no more than current nutrient status. Such analysis offers guidance for future fertilizer and soil-management practices, but tells little about the potential available supply of any given nutrient in the soil. It is also unlikely, save on the basis of considerable experience, that the analysis will allow for predictions about the nutrients or factors which will next prove limiting once the original condition is corrected.

As to basic concepts some, for example Macy (1946) believe that for any given plant there exists a fixed "critical percentage" for each nutrient; amounts in excess of this percentage representing luxury consumption, and amounts below representing a "poverty adjustment range" until a "minimal percentage" is reached. The critical percentage is thought of as "ideal" and subject perhaps to some slight variation depending upon other growth factors, but it is regarded essentially as a "fixed" value, characteristic for a given plant of given age. Macy thus visualizes three ranges or portions of a curve relating plant response to percentage concentration: (1) a narrow minimum percentage range where response may increase but internal concentration remains constant; (2) a poverty adjustment range where both response and internal concentration rise; and (3) a luxury consumption range in which response remains constant but concentration increases.

Ulrich (1948) combines the concept of critical nutrient levels in the plant with the "limiting factor" idea of plant growth. He thinks that for any given element and plant part the eritical nutrient level probably represents a narrow range of concentrations.

Goodall and Gregory (1947) have discussed theory at some length, and note that plant growth is conditioned by two sets of factors : (1) the external factors such as light, temperature, and water and nutrient supply; (2) internal factors, mainly nutritive but including hormones. They continue:

"With regard to the intensity level of all these factors the following generalization is possible, namely, that for each factor in turn there is an optimum level and that growth is increased if the intensity is brought to this level and decreased if it is raised further. These optima are not fixed but depend upon all factors simultaneously; nevertheless, in theory one may postulate an optimal concatenation of factors at which development of the plant would be maximal and that no greater rate could be attained by alteration in the level of any one or more factors. The maximal yield of the plant would then be secured and would be determined entirely by internal genetic factors. Assuming then that all external factors including all nutrients except one are 
maintained at optimal level, then as this is raised growth made will be a function solely of the available amount of this single nutrient, and as the optimum is approached the 'maximum possible yield' of the plant will be reached."

These concepts have much in common. However, until a more complete understanding of plant growth and the functions and interrelations of nutrient elements is at hand, it will be difficult if not impossible to lay down a law or principle, applicable to all plants, which completely describes the relationship of nutrient content to plant performance. The practical need is for more data about this relationship.

As to specific work on citrus, much less has been published to date than on certain other plants such as the apple. In 1935 Hardy, McDonald and Rodriguez, working on grapefruit, suggested nutrient ratios in leaf ash composition for assessing the nutrient status of the soil, and proposed the composition of certain high-performance trees as standards. At that time no such standards were locally available for grapefruit, and the authors made use of published analyses of California citrus trees presumed to be satisfactory. The leaf composition of the California average ("ideal") selected was as follows : ash, 17.7 per cent in the dry matter; nitrogen, 13.5 per cent; $\mathrm{P}_{2} \mathrm{O}_{5}, 2.1$ per cent; $\mathrm{K}_{2} \mathrm{O}$, 7.2 per cent; $\mathrm{CaO}, 48.4$ per cent; and $\mathrm{MgO}$, 4.5 per cent of total ash.

Leaf analysis of high performance trees is a useful approach, but must be supported by evidence showing that such standards have a fixed or unique value. In the absence of such evidence one might justifiably assume that equally good performance may be possible with another set of values or ratios. Bathurst $(1943,1944)$ in South Africa has been studying leaf analysis methods as applied to valencia orange trees, and though no standards have as yet been published certain tentative levels for the different elements have been fixed, and in private correspondence it is indicated that-as with Hardy et al.-standardization is being accomplished by leaf analysis of high-performance orchards. Bathurst includes a wider group of groves in his study, and these data should lead to values of much greater significance than is possible where only one or at best a few groves are used as standards.

Applying the sampling technique worked out by Bathurst and such data as are available, Oppenheimer (1945) has analyzed leaves of Shamouti orange from various groves in Palestine, and obtained results considered useful in fertilizer recommendations in that country. The total nitrogen content of leaves from various groves ranged from 1.38 to 3.05 per cent. Oppenheimer thinks that 2.0 per cent nitrogen marks a low level and 2.5 per cent an ample supply. Innes (1946) working with grapefruit in Jamaica suggests the following critical values as percentage of dry matter of the leaf : nitrogen, 2.3 per cent, phosphorus less than 0.13 per cent, and potassium about 1.1 per cent.

\section{EXPERIMENTAL PROCEDURE}

In our efforts to test the value of tissue analysis and develop methods for diagnosing the potassium status of citrus trees, we have made use of information from three major sources: (1) controlled-culture experiments with citrus; (2) field-fertilizer experiments with citrus; and (3) data derived from high-yielding citrus orchards. 


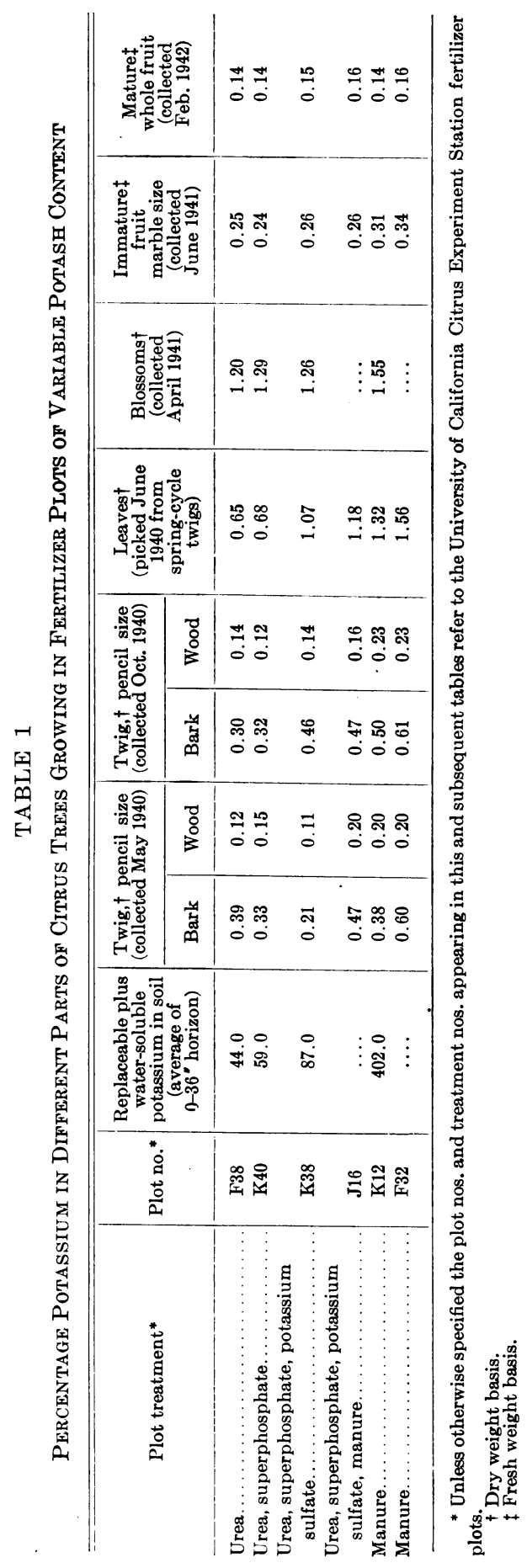


The two most important experiments which provided material for this study were : (1) a large-scale outdoor nutritional experiment with navel and valencia orange trees growing in solutions of graded potassium content. A detailed account of this experiment has been published by Chapman, Brown, and Rayner (1947). (2) The Citrus Experiment Station long-time fertilizer experiment trials with navel oranges. Reference to this experiment may be found in two publications, one by Batchelor, Parker, and McBride (1928), the other by Parker and Batchelor (1942). This experiment involves 44 different fertilizer treatments. Some of these, in addition to supplying ample nitrogen, have resulted in the accumulation of considerable potassium in the soil. This experiment has been an especially valuable source of plant material for testing out a number of questions raised in this study.

\section{Method of Handling and Analyzing Leaves}

Except where otherwise specified, the analyses reported in this paper were made on composite samples of leaves of sufficient number and size-gradation to overcome the leaf-variability factor. (No detailed statistical study has been made, but sufficient data are available to show that for any given nutrient element, differences in reported values of greater than 10 per cent are significant.)

The leaves were individually washed in tapwater, rinsed with distilled water, dried at $50^{\circ} \mathrm{C}$, ground, and stored in stoppered bottles. Potassium was determined by the cobaltinitrite method as outlined by Wilcox (1937). Other constituents such as calcium, magnesium, sodium, nitrogen, phosphorus, sulfur, chlorine, and ash were determined by accepted methods of analysis.

\section{RESULTS}

\section{Part of Plant Most Indicative of Potassium Level in Soil}

There is evidence that with many plants the leaf is well suited for indicating nutrient status. It does not follow, however, that this is true for all plants, nor that for any given plant the leaf is best for estimating the adequacy of all elements. To secure information as to what part of an orange tree best reflects potassium status, tests were made on composite samples of leaves, twig bark, blossoms, immature fruit, and mature fruit, of navel orange trees growing in a series of differentially fertilized plots of the University of California Citrus Experiment Station trials. The plots from which samples were taken were those showing a wide range of potassium in the soil (the result of differential fertilizer treatment carried on over 13 years). The results, presented in table 1, show that the leaves from trees in the different plots varied about as widely, and were better related to soil values, than the other parts tested. Twig bark was next in line; fruit was the least reflective of soil supply.

\section{Part of Leaf Most Indicative}

Leaf petioles have been given preference over leaf blades with some plants such as grapes, sugar beets, and Ladino clover (Ulrich, 1948; Lorenz, 1942). It therefore seemed desirable to check on this question with reference to citrus. A large composite sample of navel orange leaves (spring cycle) was picked on August 16, 1943, from all the trees of replicate plots of the calcium nitrate 
and manure treatments, respectively, of the fertilizer trials. Large differences in potassium content of the soils of these two treatments existed at the time of sampling. After cleaning, the petioles were separated from the leaf blades and each analyzed separately for total calcium, potassium, and phosphorus. Table 2 shows that the petioles, though slightly lower in potassium and phosphorus than the leaf blades, appear to offer no advantage over the blade as regards sensitivity to potash.

TABLE 2

Blades Versus Petioles as Indicators of Nutritional Status

\begin{tabular}{|c|c|c|c|c|c|c|c|}
\hline \multirow{3}{*}{ Plot treatment } & \multirow{3}{*}{ Plot no. } & \multicolumn{6}{|c|}{ Composition in per cent of dry matter* } \\
\hline & & \multicolumn{2}{|c|}{ Calcium } & \multicolumn{2}{|c|}{ Potassium } & \multicolumn{2}{|c|}{ Phosphorus } \\
\hline & & Blades & Petioles & Blades & Petioles & Blades & Petioles \\
\hline \multirow[t]{4}{*}{ Calcium nitrate, winter cover crop } & D32 & 4.96 & 4.87 & .86 & .79 & .189 & .147 \\
\hline & H24 & 5.00 & 4.86 & .93 & .80 & .192 & .154 \\
\hline & I40 & 4.93 & 4.82 & .85 & .79 & .204 & .152 \\
\hline & L12 & 4.76 & 4.71 & .84 & .77 & .200 & .167 \\
\hline Average. . & & 4.91 & 4.81 & .87 & .79 & .196 & .155 \\
\hline \multirow[t]{4}{*}{ Manure, winter cover crop } & D54 & 4.42 & 4.61 & 1.49 & 1.42 & .192 & .160 \\
\hline & G46 & 4.76 & 4.23 & 1.62 & 1.50 & .190 & .157 \\
\hline & 126 & 4.25 & 4.27 & 1.68 & 1.61 & .201 & .156 \\
\hline & K12 & 4.80 & 4.80 & 1.56 & 1.55 & .203 & .167 \\
\hline Average.$\ldots \ldots \ldots \ldots \ldots \ldots \ldots$ & & 4.43 & 4.48 & 1.59 & 1.52 & .196 & .160 \\
\hline
\end{tabular}

* Each analysis was made on samples derived from spring-cycle twigs; 20 to 30 leaves were picked from each of the 8 navel orange trees in each plot and composited into one large sample. The petioles were separated from the blades and each analyzed separately. The leaves were collected on Aug. 16, 1943.

\section{Kind and Age of Leaves Most Indicative of Potassium Status}

The above data indicate that total potassium in the leaf reflects potassium variations in the soil better than any of the other plant parts tested. The question arises next whether leaves of one age or cycle are better suited than those of other ages or cycles. Citrus trees are evergreen and leaf growth is cyclic. One flush of leaf and twig growth occurs in the spring at time of bloom (the orange fruit is borne, save for "off-bloom," on the terminals of this spring growth); another flush of growth under California conditions follows usually in June, and another in August or September.

To determine whether one growth cycle showed any advantage over another in reflecting potassium variations in the soil, nonfruit-bearing twigs of both the spring and June cycles were tagged for identification, and composite leaf samples collected from these at periodic intervals for from 10 to 12 months thereafter. Trees of two contrasting fertilizer plots were chosen, one receiving urea alone, in which the soil level of potash was relatively low, and the other receiving manure, in which the potash was high.

The data (table 3 ) show that the June or summer-cycle leaves systematically averaged a little higher in this element than the spring leaves, but that the spread in potassium between the two plots was somewhat wider with the spring flush. 


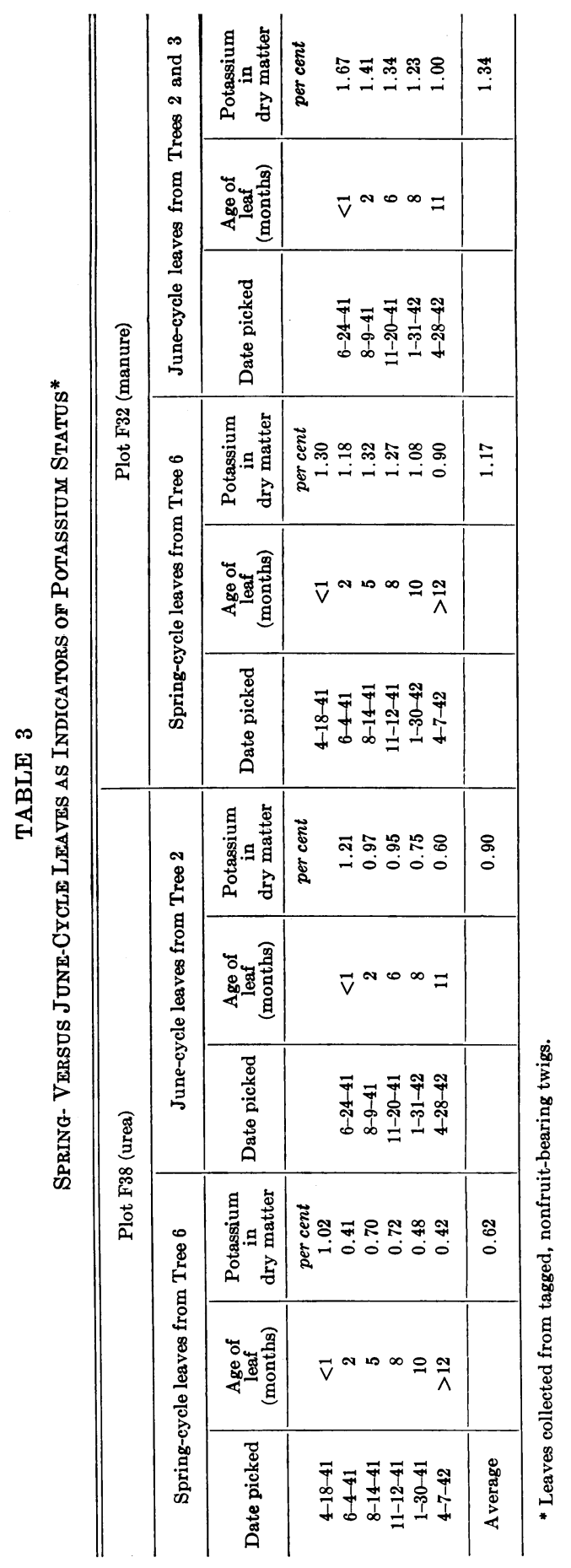




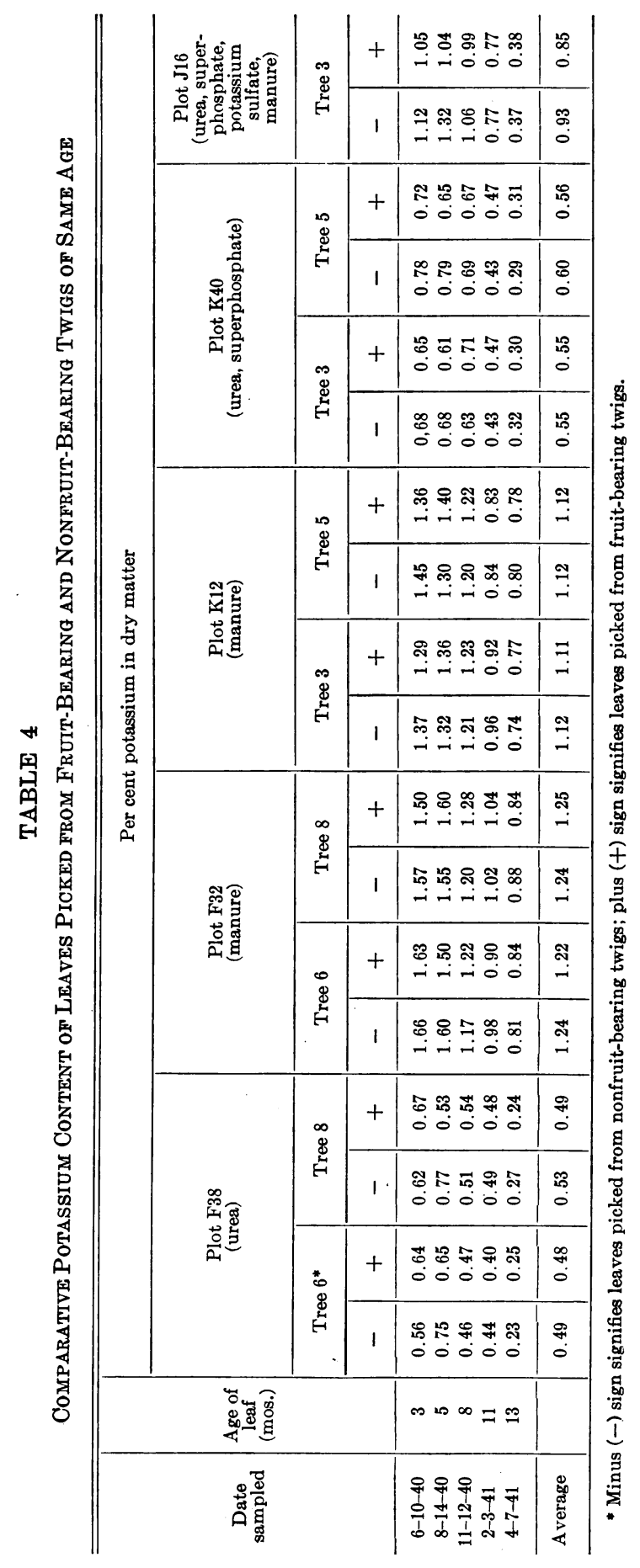




\section{Effect of Fruit on Leaf Composition}

To determine whether spring-cycle leaves from fruit-bearing twigs show different potash levels and trends than those of nonfruit-bearing twigs, both types were tagged and leaf samples taken at periodic intervals for 10 months. Individual trees in each of five differentially fertilized plots were sampled for this study. Table 4 shows that the potassium in some cases is slightly lower in the leaves from fruit-bearing twigs, but the difference if real is very slight, and of doubtful consequence.

TABLE 5

Change in Potassium Percentage of Leaves with Age*

\begin{tabular}{|c|c|c|c|c|c|c|c|}
\hline \multirow[b]{2}{*}{ Year* } & \multirow[b]{2}{*}{$\begin{array}{l}\text { Date of } \\
\text { picking }\end{array}$} & \multirow[b]{2}{*}{$\begin{array}{c}\text { Age of } \\
\text { leaf } \\
\text { (months) }\end{array}$} & \multicolumn{5}{|c|}{ Per cent potassium in dry matter } \\
\hline & & & $\begin{array}{c}\text { Plot F38 } \\
\text { (urea) }\end{array}$ & $\begin{array}{c}\text { Plot F3 } \\
\text { (manure) }\end{array}$ & $\begin{array}{c}\text { Plot K12 } \\
\text { (manure) }\end{array}$ & $\begin{array}{c}\text { Plot J16 } \\
\text { (urea, super- } \\
\text { phosphate, } \\
\text { potassium } \\
\text { sulfate, } \\
\text { manure) }\end{array}$ & Average \\
\hline $1940-41$ & $\begin{array}{l}6-10-40 \ldots \\
8-14-40 \ldots \\
11-12-40 \ldots \\
2-3-41 \ldots \\
4-7-41 \ldots\end{array}$ & \begin{tabular}{r|}
3 \\
5 \\
8 \\
11 \\
13
\end{tabular} & $\begin{array}{l}0.65 \\
0.59 \\
0.50 \\
0.44 \\
0.24\end{array}$ & $\begin{array}{l}1.56 \\
1.55 \\
1.25 \\
0.97 \\
0.84\end{array}$ & $\begin{array}{l}1.32 \\
1.38 \\
1.22 \\
0.87 \\
0.78\end{array}$ & $\begin{array}{l}1.18 \\
1.13 \\
1.01 \\
0.75 \\
0.39\end{array}$ & $\begin{array}{l}1.18 \\
1.16 \\
0.99 \\
0.76 \\
0.56\end{array}$ \\
\hline $1941-42$ & $\begin{array}{l}6-4-41 \ldots \\
8-14-41 \ldots \\
11-12-41 \ldots \\
1-30-42 \ldots\end{array}$ & $\begin{array}{r}3 \\
5 \\
8 \\
11\end{array}$ & $\begin{array}{l}0.44 \\
0.60 \\
0.62 \\
0.47\end{array}$ & $\begin{array}{l}1.06 \\
1.29 \\
1.32 \\
1.14\end{array}$ & $\begin{array}{l}1.20 \\
1.29 \\
1.17 \\
1.11\end{array}$ & $\begin{array}{l}1.04 \\
0.98 \\
1.03 \\
0.95\end{array}$ & $\begin{array}{l}0.93 \\
1.04 \\
1.03 \\
0.92\end{array}$ \\
\hline 1943 & $\begin{array}{l}6-8-43 \ldots \ldots \\
7-6-43 \ldots \\
8-6-43 \ldots \\
9-2-43 \ldots \\
10-4-43 \ldots \\
11-3-43 \ldots\end{array}$ & $\begin{array}{l}3 \\
4 \\
5 \\
6 \\
7 \\
8\end{array}$ & $\begin{array}{l}0.73 \\
0.58 \\
0.59 \\
0.64 \\
0.55 \\
0.57\end{array}$ & $\begin{array}{l}1.27 \\
1.24 \\
1.15 \\
1.20 \\
1.14 \\
1.08\end{array}$ & $\begin{array}{l}1.04 \\
1.22 \\
1.15 \\
1.30 \\
1.28 \\
1.17\end{array}$ & $\begin{array}{l}1.17 \\
1.21 \\
1.18 \\
1.12 \\
0.91 \\
0.70\end{array}$ & $\begin{array}{l}1.05 \\
1.06 \\
1.02 \\
1.06 \\
0.97 \\
0.90\end{array}$ \\
\hline
\end{tabular}

- The 1940 data are averages drawn from table 4 and refer to leaves from fruit-bearing spring-cycle twigs; the data for 1941,1942 , and 1943 are averages of several trees in each of these plots sampled at successive dates, the leaves being from spring-cycle fruit-bearing twigs.

\section{Effect of Age of Leaf}

This problem has been studied in considerable detail and data from two sources are presented in tables 5 and 6 . The data of table 5 were derived from analyses of composite samples of leaves picked from several trees respectively in each of four different fertilizer plots. Data for three different seasons are shown. In all cases the leaves for any one series were picked from fruit-bearing twigs of that spring's cycle. In most instances the youngest leaves were higher in potassium than the oldest leaves, and in some instances there was a progressive potassium diminution with age. But this was not true in all cases. Thus, while in the 1940-1941 set there was a progressive reduction of potassium percentage with age, leaves from these same trees in 1941-1942 were essentially constant in composition on the August and November sampling dates, then dropped off some in January. 


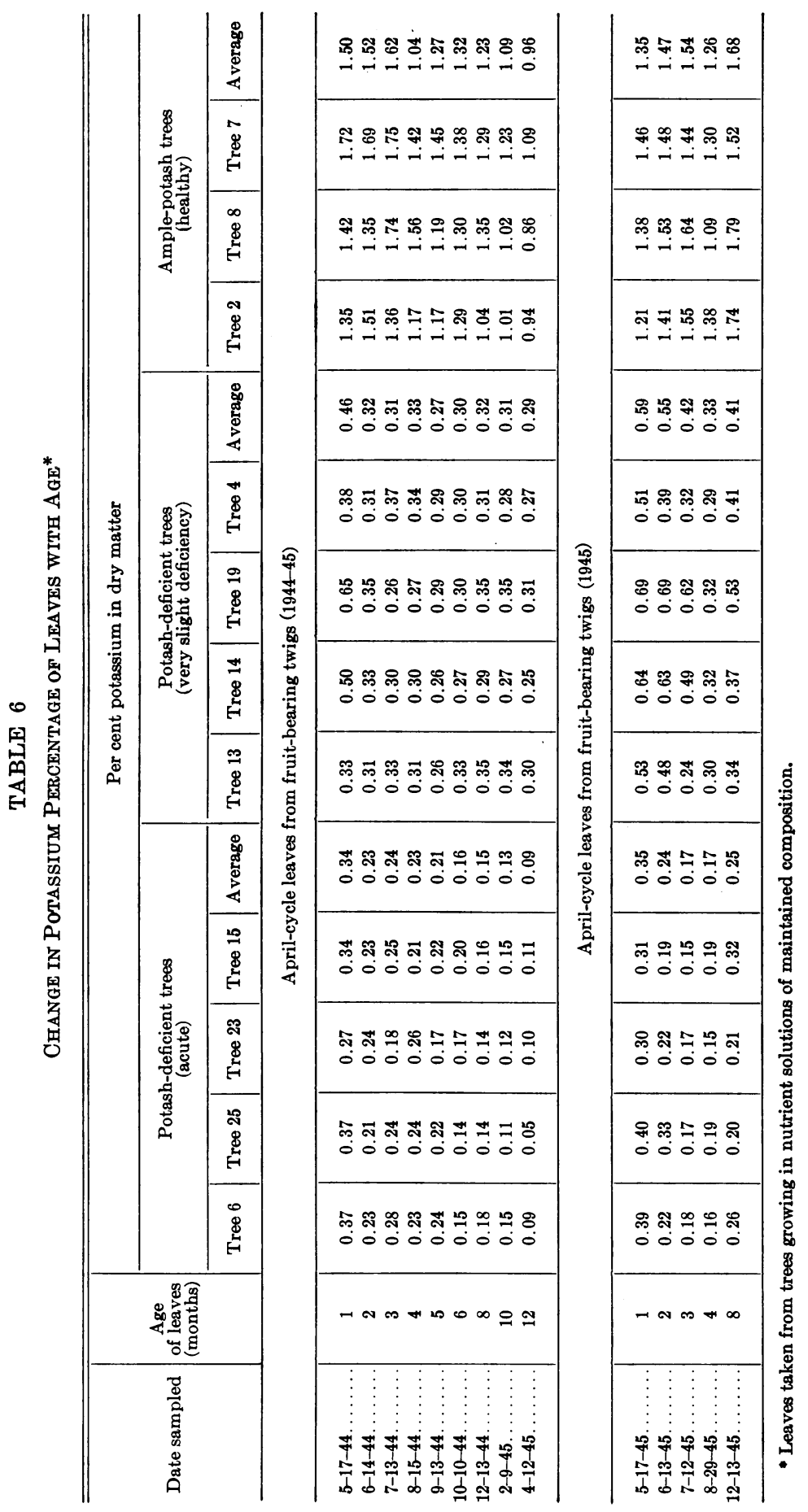


A more detailed record was obtained on individual trees in the outdoor nutritional experiment. Beginning in May of two successive years, leaves were picked from spring-cycle fruit-bearing twigs at frequent intervals. Three groups of trees were included in this study: those acutely deficient in potash, those slightly deficient, and those receiving an ample supply. These data (table 6 ) with table 5 show that by April, at the time of bloom, the year-old or nearly year-old leaves are definitely lower in potassium than at any other time. These and other data indicate a translocation of potassium from older trees at this time to supply the needs of the bloom and new cycle growth. Moreover, the difference in potassium content between leaves from trees lacking potash and those amply supplied is somewhat greater at this time than earlier. It would appear from this evidence that the best time of year to sample trees would be in the spring at the time of the blossom and growth cycle, choosing leaves from twigs of the previous year's spring cycle.

But there are two objections to the choice of such leaves. In many orchards-particularly navel-the fruit has usually been picked, and some difficulty would be encountered in definitely distinguishing the year-old springcycle twigs from subsequent, and in some cases former growth cycles. A second objection is that the use of leaves of this age would restrict sampling to the short spring period when bloom is at its peak. June to November leaves, which do not have these disadvantages, are reasonably stable in leaf composition and show an adequate spread in potassium percentage of leaves among trees growing under variable potassium supply conditions. Hence for the present we have chosen to standardize on spring-cycle leaves from three to seven months old, and from fruit-bearing twigs only. Such leaves are definitely dated.

\section{Year-to-Year Fluctuations of Potassium in Leaves from Trees Grown under Uniform Nutrition}

One question which came up was whether leaves of similar age from orange trees growing under conditions of uniform culture would show the same potash values from one year to the next. An excellent opportunity to test this question was presented by the outdoor culture experiment, where three groups of trees were grown in solutions of constant composition. Leaf-analysis data for two consecutive years (1944-1945) are presented in table 7. (The data of table 7 were drawn from table 6 to illustrate the present point.) Considering all the factors that might conceivably affect potassium percentage in one year as against the next-e.g., variations in fruit produced, and other factors which might influence rates of absorption, translocation, growth, photosynthesisthe values obtained are remarkably constant. The three groups of trees kept the same appearance over the two years studied.

Table 8 gives year-to-year potassium percentage in similarly aged leaves from individual trees of several uniformly treated fertilizer plots. The leaf values of these field trees show considerably greater yearly variations than those of the culture experiment. From these and other data we conclude that under field conditions, similarly aged foliage from trees not deficient in potassium may show fairly wide potassium fluctuations from one year to the next; however, under conditions of potassium deficiency, and where the degree of deficiency is constant, fairly uniform values are likely to be found. 


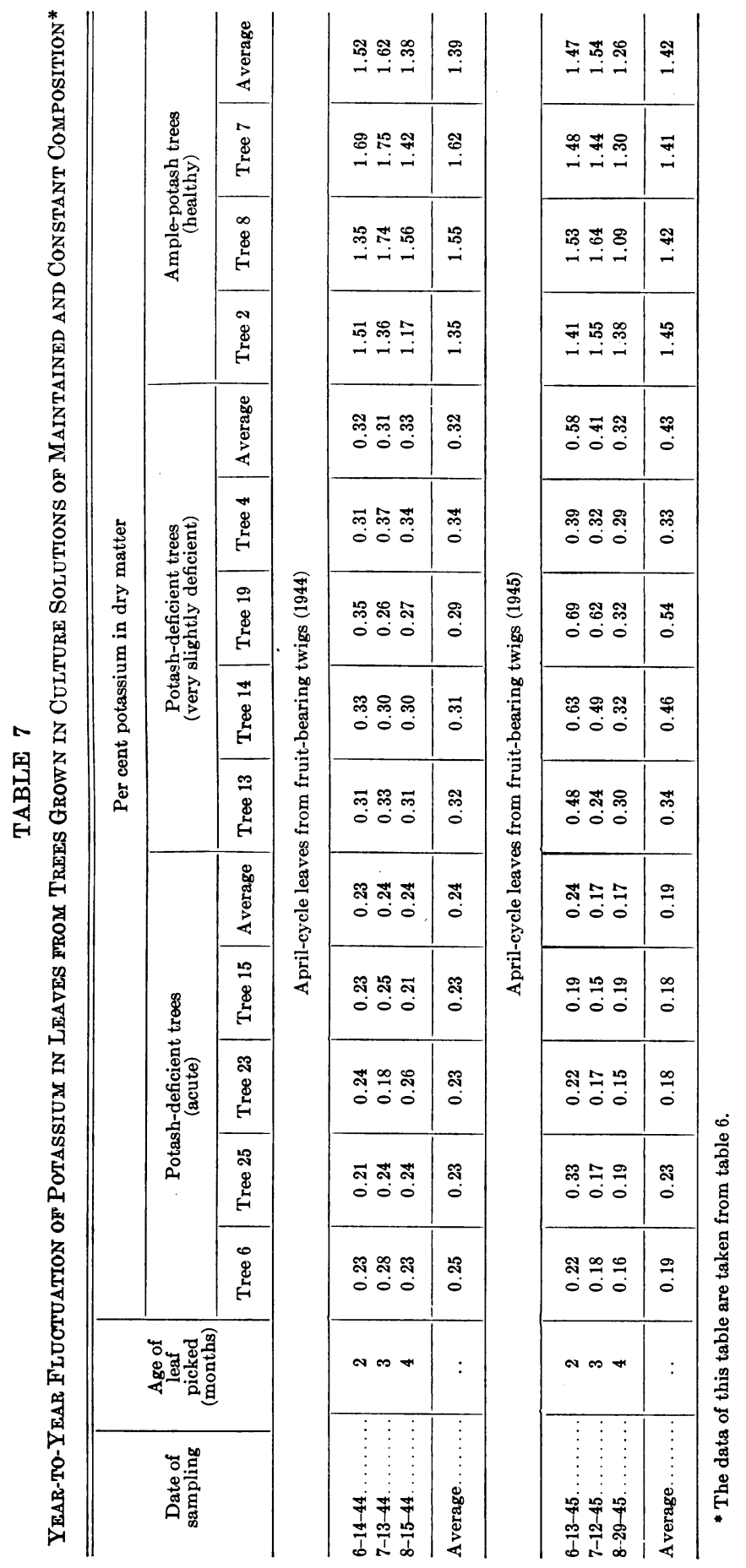









\section{Effect of Crop on Potassium Status of Leaf}

From the fact that the potassium levels of leaves borne on fruit-bearing and nonfruit-bearing twigs are essentially the same, we might infer that yield fluctuations from year to year exert little effect on leaf potassium levels. Data bearing on this inference were obtained in a special experiment, in which nearly all of the young fruit were picked from two valencia trees, and the

TABLE 9

EFfect of Defruiting Trees on Composition of SPRING-Cycle Leates

\begin{tabular}{|c|c|c|c|c|c|c|c|c|c|c|c|c|}
\hline \multirow{3}{*}{$\begin{array}{c}\text { Date } \\
\text { sampled }\end{array}$} & \multirow{3}{*}{$\begin{array}{c}\text { Age of } \\
\text { leaf } \\
\text { (months) }\end{array}$} & \multirow{3}{*}{ Tree } & \multicolumn{10}{|c|}{ Composition in per cent of dry matter } \\
\hline & & & \multicolumn{2}{|c|}{$\mathrm{Ca}$} & \multicolumn{2}{|c|}{$\mathrm{Mg}$} & \multicolumn{2}{|c|}{$\mathbf{K}$} & \multicolumn{2}{|c|}{$\mathrm{N}$} & \multicolumn{2}{|c|}{$\mathbf{P}$} \\
\hline & & & $-*$ & + & - & + & - & + & - & + & 一 & + \\
\hline \multirow[t]{2}{*}{$6-8-43 \ldots$} & 3 & 1 & 2.91 & 3.14 & .30 & .24 & .86 & .85 & 2.80 & 2.69 & .144 & .141 \\
\hline & & 2 & 2.84 & 2.84 & .25 & .28 & .94 & .94 & 2.78 & 2.80 & .157 & .140 \\
\hline \multirow[t]{2}{*}{$7-6-43 \ldots$} & 4 & 1 & 3.63 & 3.93 & .33 & .32 & 1.15 & 1.02 & 3.00 & 2.96 & .151 & .144 \\
\hline & & 2 & 3.77 & 3.79 & .29 & .32 & 1.15 & 1.16 & 3.09 & 3.05 & .166 & .148 \\
\hline \multirow[t]{2}{*}{$8-5-43 \ldots$} & 5 & 1 & 3.84 & 4.90 & .32 & .33 & 1.15 & .84 & 3.03 & 2.79 & .160 & .135 \\
\hline & & 2 & 4.16 & 4.12 & .33 & .35 & 1.16 & .92 & 3.11 & 2.74 & .154 & .137 \\
\hline \multirow[t]{2}{*}{$9-2-43 \ldots$} & 6 & 1 & 4.67 & 4.84 & .33 & .30 & .95 & .93 & 3.05 & 3.08 & .141 & .143 \\
\hline & & 2 & 4.87 & 4.81 & .32 & .29 & .87 & .92 & 3.03 & 3.05 & .149 & .138 \\
\hline \multirow[t]{2}{*}{$10-4-43}$. & 7 & 1 & 4.68 & 4.93 & .29 & .30 & .97 & .83 & 3.01 & 2.80 & .128 & .132 \\
\hline & & 2 & 4.89 & 4.88 & .33 & .29 & .88 & .84 & 3.03 & 2.95 & .138 & .137 \\
\hline \multirow[t]{2}{*}{$11-3-43}$. & 8 & 1 & 4.70 & 4.89 & .30 & .30 & .86 & .83 & 2.86 & 2.70 & .115 & .130 \\
\hline & & 2 & 4.68 & 4.79 & .31 & .32 & .88 & .80 & 2.86 & 2.82 & .128 & .128 \\
\hline Average & & & 4.14 & 4.32 & .31 & .30 & .98 & .91 & 2.97 & 2.87 & .144 & .138 \\
\hline
\end{tabular}

* Minus sign (-) indicates those trees from which a large part of the young fruit was picked following spring bloom; plus sign ( + indicates trees, serving as checks, on which the fruit was allowed to remain. Leaves in both sets of trees were taken from nonfruit-bearing spring-cycle twigs.

potassium of their leaves compared with that of adjacent trees allowed to bear their regular crop of fruit. Spring-cycle leaves, picked at successive months beginning in June from mature valencia orange trees growing under uniform conditions, were the subject of study. The leaves were analyzed for calcium, magnesium, nitrogen, and phosphorus in addition to potassium. The data are presented in table 9 and show that the magnesium, potassium, nitrogen and phosphorus in leaves from the fruit-bearing trees are all somewhat lower, though to a very small degree.

Table 10 presents the effect of late versus early picking of valencia oranges on the mineral composition of leaves. In this experiment the mature valencia fruit from one series of rows was picked early in the season (April), and in the other rows allowed to remain on the trees until fall (October). Leaves from spring-cycle fruit-bearing branches were picked from the two sets of trees in August. The data show little if any significant difference. 
The evidence of tables 9 and 10, while incomplete and presenting some uncertainties in interpretation, suggests that the yearly fluctuations in potassium in similarly aged leaves noted in table 8 are likely due to causes other than the variable amounts of fruit borne from year to year. So far as potassium is concerned, that which goes into the orange fruit does not appear to be drawn primarily from the leaf supply; it is probably carried directly to the fruit by the transpiration stream.

\section{Effect of Nutrient Deficiencies on Potassium Content of Leaf}

In evaluating nutrient status it is desirable to know the effect of a deficiency or excess of one element on the level of other elements in the leaf. The effect

TABLE 10

Effect of Early and Late Picking of Oranges on Leaf Composition*

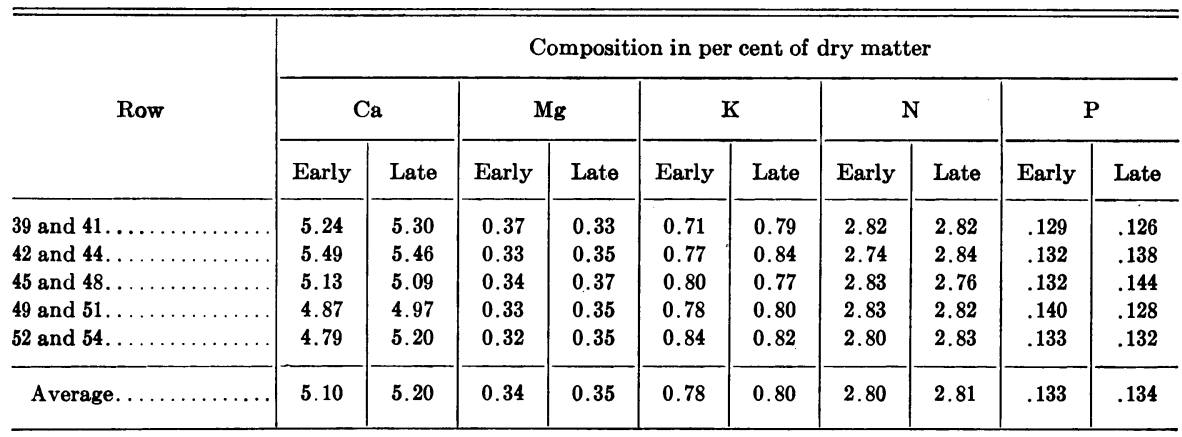

* Leaves picked August 23, 1943, from spring-cycle fruit-bearing twigs.

of various nutrient deficiencies on the potassium content of citrus leaves is presented in the following section.

Nitrogen deficiency. In the Citrus Experiment Station fertilizer plots with Washington navel oranges, the trees of plots receiving no nitrogen fertilizer were markedly deficient in this element. Leaf samples (spring cycle from both fruit-bearing and nonfruit-bearing twigs) were collected in July and again in August, 1943, from the no-nitrogen, the urea, and the calcium nitrate plots respectively. The latter two plots are well supplied with nitrogen and the trees were green. The data (table 11) show that the potassium accumulates markedly in leaves of nitrogen-deficient trees. There is also a substantial accumulation of phosphorus, but calcium and magnesium are somewhat decreased.

Phosphorus deficiency. An opportunity to test the effect of phosphorus deficiency on potassium and other nutrient levels in the leaf was afforded by a nutritional experiment with trees growing out-of-doors in solutions of varying maintained phosphorus levels. The trees were Washington navel oranges budded on sour root, and the experiment was begun in 1940 with one-year-old budded trees. Successive phosphate increases in the cultures were accomplished by adding increasing amounts of monosodium phosphate to the base culture solution. Five different levels of phosphate were maintained. The lowest was maintained at concentrations varying from 2.5 to 3.5 p.p.m. $\mathrm{PO}_{4}$. 
The trees of these cultures were all mildly deficient in phosphate as judged by growth and tree symptoms. The highest level was maintained at concentrations varying between 150 and 175 p.p.m. $\mathrm{PO}_{4}$.

In 1943 and again in 1944 leaves from the current spring-cycle twigs were picked in July, August and September and analyzed for calcium, magnesium, potassium, nitrogen, and phosphorus. The data (table 12) show that with phosphorus-deficient trees there was a tendency for potassium to accumulate in the leaf. Nitrogen was also significantly higher in the leaves of phosphorus-

TABLE 11

Effect of Nitrogen Deficiency on Inorganic Composition of Orange Leaves

\begin{tabular}{|c|c|c|c|c|c|c|c|c|c|c|c|c|}
\hline \multirow{3}{*}{$\begin{array}{c}\text { Plot } \\
\text { treatment }\end{array}$} & \multirow{3}{*}{$\begin{array}{c}\text { Tree } \\
\text { condition }\end{array}$} & \multirow{3}{*}{ Plot no. } & \multicolumn{10}{|c|}{ Composition in per cent of dry matter } \\
\hline & & & \multicolumn{5}{|c|}{ Picked in July* } & \multicolumn{5}{|c|}{ Picked in August* } \\
\hline & & & $\mathrm{Ca}$ & $\mathbf{M g}$ & $\mathbf{K}$ & $\mathrm{N}$ & $\mathbf{P}$ & $\mathrm{Ca}$ & $\mathbf{M g}$ & $\mathbf{K}$ & $\mathrm{N}$ & $\mathbf{P}$ \\
\hline \multirow{5}{*}{$\begin{array}{l}\text { Cover crop } \\
\text { alone }\end{array}$} & \multirow{5}{*}{$\begin{array}{l}\text { Extreme } \\
\text { nitrogen } \\
\text { deficiency }\end{array}$} & D12. & 4.28 & 0.28 & 1.29 & 2.13 & .188 & 5.15 & 0.33 & 1.04 & 2.15 & .206 \\
\hline & & H32. & 4.30 & 0.24 & 1.56 & 2.26 & .312 & 4.74 & 0.31 & 1.38 & 2.44 & .304 \\
\hline & & J4 . & 4.85 & 0.31 & 1.15 & 2.27 & .250 & 5.55 & 0.31 & 1.03 & 2.24 & .229 \\
\hline & & L22. & 4.50 & 0.39 & 1.44 & 2.16 & .242 & 4.69 & 0.36 & 1.41 & 2.25 & .218 \\
\hline & & Average... & 4.48 & 0.30 & 1.36 & 2.20 & .248 & 5.03 & 0.33 & 1.21 & 2.27 & .239 \\
\hline \multirow{5}{*}{$\begin{array}{l}\text { Urea, cover } \\
\text { crop }\end{array}$} & \multirow[t]{5}{*}{ Healthy } & F50. & 5.20 & 0.48 & 0.62 & 2.64 & .145 & 5.16 & 0.35 & 0.60 & 2.60 & .143 \\
\hline & & & 5.59 & 0.38 & 0.49 & 2.72 & .136 & 5.54 & 0.36 & 0.57 & 2.79 & .134 \\
\hline & & K28. & 5.34 & 0.37 & 0.58 & 2.59 & .139 & 5.18 & 0.35 & 0.64 & 2.78 & .132 \\
\hline & & M12 . . . & 4.90 & 0.37 & 0.62 & 2.82 & .160 & 4.90 & 0.38 & 0.64 & 2.80 & .156 \\
\hline & & Average........ & 5.26 & 0.40 & 0.58 & 2.69 & .145 & 5.19 & 0.36 & 0.61 & 2.74 & .141 \\
\hline \multirow{5}{*}{$\begin{array}{l}\text { Calcium } \\
\text { nitrate, } \\
\text { cover } \\
\text { crop }\end{array}$} & \multirow[t]{5}{*}{ Healthy } & D32. & 4.72 & 0.32 & 0.70 & 2.78 & .153 & 5.29 & 0.33 & 0.62 & 2.86 & .148 \\
\hline & & F40.. & 5.33 & 0.44 & 0.67 & 2.84 & .157 & 5.23 & 0.38 & 0.67 & 2.98 & .150 \\
\hline & & H24. & 4.70 & 0.46 & 0.68 & 2.97 & .158 & 5.68 & 0.42 & 0.75 & 2.88 & .148 \\
\hline & & $\mathrm{L} 12 \ldots$ & 4.72 & 0.35 & 0.70 & 2.32 & .152 & 5.27 & 0.35 & 0.77 & 3.07 & .142 \\
\hline & & Average..... & 4.87 & 0.39 & 0.69 & 2.73 & .155 & 5.37 & 0.37 & 0.70 & 2.95 & .147 \\
\hline
\end{tabular}

* Leaves picked from spring-cycle fruit-bearing and nonfruit-bearing twigs.

deficient trees. Magnesium was not much affected. In an earlier experiment (Chapman and Brown, 1941) analyses of both young and old leaves from phosphorus-deficient trees grown in large soil cultures, as compared with leaves from healthy trees grown under the same conditions, showed marked accumulations of potash and nitrogen; magnesium was also higher, while calcium was substantially lower. The evidence as a whole shows that potassium builds up in the leaves of phosphorus-deficient trees.

Other nutrient deficiencies. Information about other deficiencies is less complete but sufficient to indicate the trend.

The potassium content of young leaves from sulfur-deficient orange trees (Chapman and Brown, 1941) was markedly higher than that of leaves of similar age from healthy trees grown under the same conditions.

Magnesium deficiency is also accompanied by potassium increases in the leaf, as Fudge's analyses (1939) of magnesium-deficient and normal grapefruit leaves show. More recently many leaf samples from California citrus 


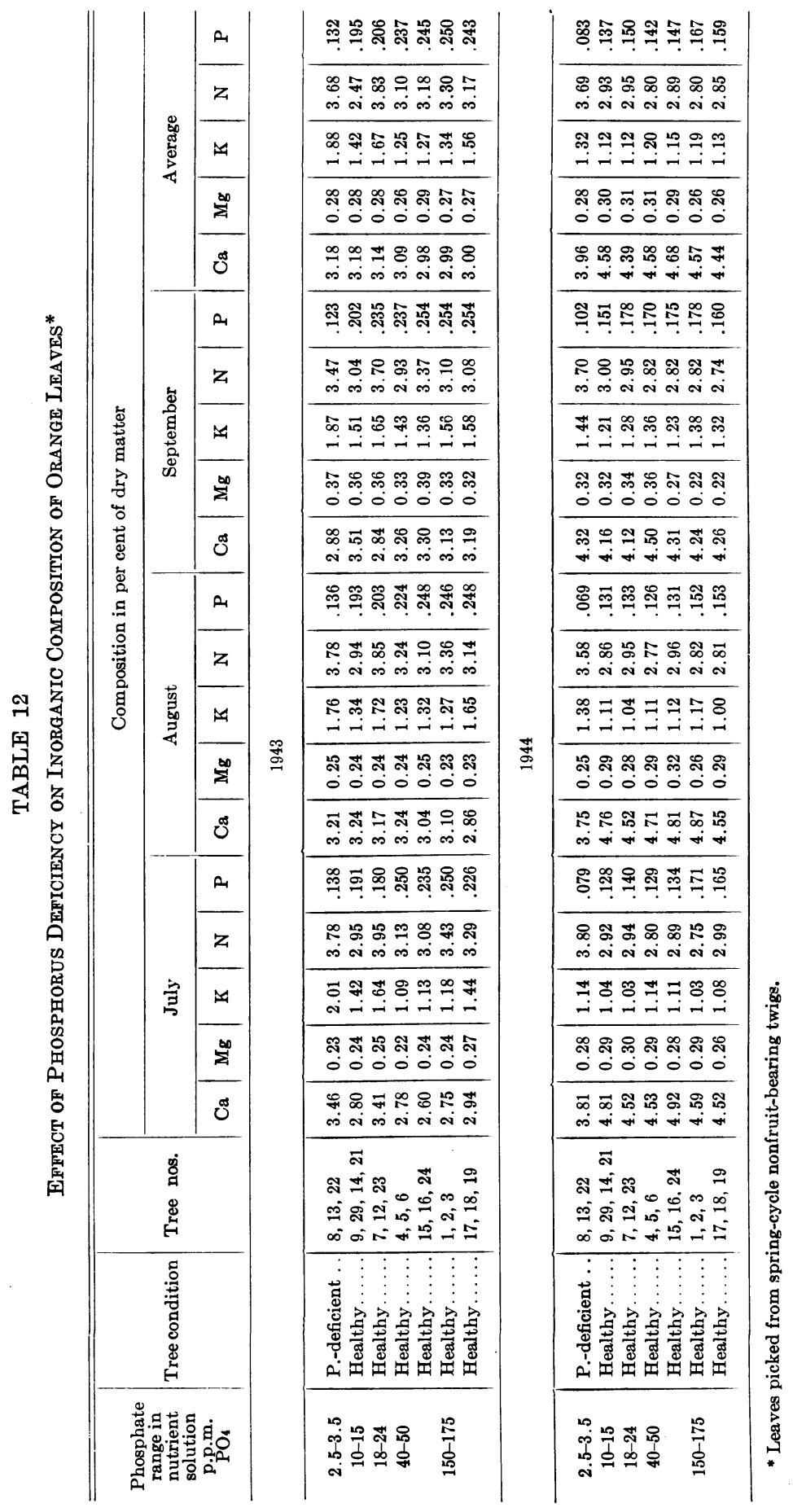


orchards showing typical magnesium-deficiency patterns have been analyzed and without exception have shown high potassium values in comparison with green leaves picked from the same trees. Similar data have been published by Haas (1948) and Parberry (1935). Hence it can be safely concluded that potassium accumulates in leaves showing typical magnesium-deficiency patterns.

Not many data are available as to the effect of calcium deficiency, but the analyses of Reed and Haas (1923) have shown that potassium was higher in leaves of young orange trees grown in calcium-free nutrient media than in those of trees receiving calcium. These data, and in addition the reciprocal relations well known to exist between these elements, make it quite certain that calcium deficiency will result in increases of potassium in the leaf.

With reference to minor element deficiencies, Kelley and Cummins (1920) published an extensive series of analyses of citrus leaves which proved conclusively that "mottled" citrus leaves contain higher potassium and lower calcium percentages than normal green leaves. Mottle leaf of citrus was subsequently shown to be caused by acute zinc deficiency. No citrus data are available with reference to iron deficiency, but since the considerable work done with other plants has generally shown that iron-deficient plants are higher in potassium and lower in calcium than normal green leaves, it is fair to infer that the same relation obtains with citrus.

No data are available with reference to copper, manganese, boron, and molybdenum deficiencies, but in view of the fact that lack of nitrogen, phosphorus, sulfur, magnesium, zine and probably iron result in potassium accumulations in the leaf, it is reasonable to suppose that the same holds with the rest of the essential elements. It seems safe to conclude that if a citrus tree is more lacking in some other element than in potassium the latter will accumulate to a greater or lesser degree in the leaf. This fact in no way invalidates the leaf test for potassium deficiency, provided it can be shown that when potassium is in deficient supply there are reasonably stable and fixed relations between percentage concentration in the leaf and degree of deficiency.

\section{Varietal and Rootstock Effects}

In the nutritional experiment with trees grown in solutions of graded potassium content referred to (Chapman, Brown, and Rayner, 1947), both navel and valencia oranges on sour stock were included. Under conditions of potassium deficiency, the potassium percentage of the leaf of both varieties came down to the same point. It would thus appear that the critical potassium level for the two varieties is the same. Under field conditions, however, analyses of leaves from commercial orchards indicate that valencia leaves are characteristically lower in potassium and higher in calcium than navel leaves. An opportunity to check this question further, and also the effect of rootstocks, was afforded by the University of California Citrus Experiment Station rootstock plots where both varieties are being grown in a series of replicated plots under uniform culture. Composite samples of spring-cycle leaves from all of the trees were collected September, 1945, and analyzed for potassium, calcium, magnesium, nitrogen, and phosphorus.

The data (table 13) show constant and significant differences between 
valencia and navel oranges which hold irrespective of rootstock. Thus the navel orange leaves show a definitely higher potassium and nitrogen content than the valencia leaves; phosphorus is slightly higher too. On the other hand calcium is definitely lower and in some cases magnesium, although with magnesium the differences are not great. With reference to rootstock effects, the leaves from trees on sour orange root, both navel and valencia, are higher in calcium and slightly lower in potassium. Nitrogen and phosphorus also appear to be a little lower. Rootstock effects of grapefruit and Sampson tangelo lie in a similar direction. Rough lemon, however, is more like sweet stock.

These data make it clear that the composition of leaves is definitely affected by rootstock and variety, and one might presume that the critical nutrient

TABLE 13

EFFects of RoOTstock aNd VARIETty on Inorganic Compositton of Leaves*

\begin{tabular}{|c|c|c|c|c|c|c|c|c|c|c|}
\hline \multirow{2}{*}{ Rootstock } & \multicolumn{5}{|c|}{$\begin{array}{l}\text { Valencia orange leaves } \\
\text { (Composition in per cent dry matter) }\end{array}$} & \multicolumn{5}{|c|}{$\begin{array}{l}\text { Washington navel orange leaves } \\
\text { (Composition in per cent dry matter) }\end{array}$} \\
\hline & $\mathbf{C a}$ & $\mathbf{M g}$ & $\mathbf{K}$ & $\mathbf{N}$ & $\mathbf{P}$ & $\mathrm{Ca}$ & Mg & $\mathbf{K}$ & $\mathbf{N}$ & $\mathbf{P}$ \\
\hline $\begin{array}{l}\text { Sweet orange (average of } \\
5 \text { varieties) } \ldots \ldots \ldots \ldots \ldots\end{array}$ & 5.97 & 0.40 & 0.49 & 2.37 & .105 & 4.84 & 0.37 & 0.90 & 2.91 & .126 \\
\hline $\begin{array}{l}\text { Sour orange (average of } \\
5 \text { varieties) } \ldots \ldots \ldots \ldots \ldots\end{array}$ & 6.75 & 0.44 & 0.42 & 2.20 & .096 & 5.43 & 0.37 & 0.80 & 2.79 & .120 \\
\hline $\begin{array}{l}\text { Grapefruit (average of } \\
2 \text { varieties) } \ldots \ldots \ldots \ldots \ldots\end{array}$ & 6.49 & 0.37 & 0.53 & 2.24 & .097 & 5.31 & 0.35 & 1.04 & 2.79 & .124 \\
\hline $\begin{array}{l}\text { Sampson tangelo (aver- } \\
\text { age of } 5 \text { plots)........ }\end{array}$ & 6.32 & 0.44 & 0.64 & 2.16 & .103 & 5.59 & 0.45 & 1.09 & 2.67 & .119 \\
\hline $\begin{array}{l}\text { Rough lemon (average } \\
\text { of } 3 \text { plots) } \ldots \ldots \ldots \ldots \ldots\end{array}$ & 5.37 & 0.48 & 0.44 & 2.63 & .114 & 4.86 & 0.48 & 0.64 & 2.85 & .120 \\
\hline
\end{tabular}

* Spring-cycle leaves from fruit-bearing branches picked in September 1945.

levels for potassium are also affected. However, our nutritional experiments and other data to be presented under the section on standardization suggest that the critical nutrient level for potassium in citrus leaves is constant and that this value holds irrespective of rootstock or variety. However, the ability of a plant to secure adequate potassium or other nutrients from a soil may be affected by variety, rootstock, and various scion-root combinations.

\section{STANDARDIZATION}

The foregoing data indicate that the leaves of citrus trees reflect potassium differences in the nutrient medium and that three- to seven-month-old springcycle leaves from either fruit-bearing or nonfruit-bearing branches are reasonably stable in composition, and, under uniform conditions of culture, show fairly constant nutrient contents from one year to the next. From work with other plants, moreover, there is ample reason to believe that under any given set of conditions in which potassium is in deficient supply, increasing deficiency within limits will be characterized by decreasing potassium percentages in the leaf. The important question is whether the critical nutrient level is a fixed value and holds under all conditions, or whether it varies depending on the confluence, or concatenation of all other factors, nutritional and otherwise, affecting growth. 
TABLE 14-Percentage Potassium and Other Inorganic Constituents in Leaves of Potas

\begin{tabular}{|c|c|c|c|c|c|c|c|c|c|c|c|}
\hline \multicolumn{11}{|c|}{ Nutrient solution in which seedlings grew } & \multirow{3}{*}{$\begin{array}{c}\text { Dry weigh } \\
\text { of whole } \\
\text { plant } \\
\text { (average } \\
\text { per plant) }\end{array}$} \\
\hline \multirow{2}{*}{$\begin{array}{l}\text { Potassium } \\
\text { status }\end{array}$} & \multirow{2}{*}{$\begin{array}{l}\text { Nitrogen } \\
\text { status }\end{array}$} & \multirow{2}{*}{$\begin{array}{c}\text { Predominant bases and other } \\
\text { characteristics }\end{array}$} & \multicolumn{8}{|c|}{ Composition in millequivalents per liter } & \\
\hline & & & $\mathrm{Ca}$ & Mg & $\mathbf{K}$ & $\mathrm{Na}$ & $\mathrm{Cl}$ & $\mathrm{NO}_{3}$ & $\mathrm{SO}_{4}$ & $\mathrm{PO}_{4}^{*}$ & \\
\hline Ample & Low & $\mathrm{Ca}$ and $\mathrm{Mg}$ & $\begin{array}{c}m e \\
3.0\end{array}$ & $\begin{array}{l}m e \\
1.50\end{array}$ & $\begin{array}{c}m \varepsilon \\
1.50\end{array}$ & $\begin{array}{c}m e \\
0.48\end{array}$ & $\begin{array}{l}m e \\
0.28\end{array}$ & $\begin{array}{c}m e \\
1.00\end{array}$ & $\begin{array}{c}m e \\
5.00\end{array}$ & $\begin{array}{c}m e \\
0.20\end{array}$ & $\begin{array}{r}\text { gms. } \\
118.0\end{array}$ \\
\hline Ample & Medium & $\mathrm{Ca}$ and $\mathrm{Mg}$. & 5.0 & 2.50 & 2.50 & 0.48 & 0.28 & 5.50 & 5.00 & 0.20 & 136.7 \\
\hline Ample & High & $\mathrm{Ca}$ and $\mathrm{Mg}$. & 12.50 & 6.25 & 6.25 & 0.48 & 0.28 & 20.00 & 5.00 & 0.20 & 142.7 \\
\hline Deficient & Low & $\mathrm{Ca}$ and $\mathrm{Mg}$. & 4.00 & 2.00 & 0.00 & 0.48 & 0.28 & 1.00 & 5.00 & 0.20 & 42.6 \\
\hline Deficient & Medium & $\mathrm{Ca}$ and $\mathrm{Mg}$. . & 6.66 & 3.34 & 0.00 & 0.48 & 0.28 & 5.00 & 5.00 & 0.20 & 26.9 \\
\hline Deficient & High & $\mathrm{Ca}$ and $\mathrm{Mg} \ldots \ldots \ldots$ & 16.66 & 8.34 & 0.00 & 0.48 & 0.28 & 20.00 & 5.00 & 0.20 & 32.8 \\
\hline Deficient & High & Mg. & 5.00 & 20.00 & 0.00 & 0.48 & 0.28 & 20.00 & 5.00 & 0.20 & 47.8 \\
\hline Deficient & High & $\mathrm{Na} \ldots \ldots \ldots \ldots \ldots \ldots \ldots$ & 4.00 & 2.00 & 0.00 & 19.48 & 0.28 & 20.00 & 5.00 & 0.20 & 45.4 \\
\hline Deficient & Medium & $\mathrm{Ca}$ and $\mathrm{Mg}$, high sulfate.... & 16.66 & 8.34 & 0.00 & 0.48 & 0.28 & 5.00 & 20.00 & 0.20 & 30.4 \\
\hline Deficient & Medium & $\mathrm{Ca}$ and $\mathrm{Mg}$, high chloride... & 19.33 & 9.67 & 0.00 & 0.48 & 19.28 & 5.00 & 5.00 & 0.20 & 38.5 \\
\hline Deficient & Medium & $\mathrm{Na}$ and high chloride......... & 6.66 & 3.34 & 0.00 & 19.48 & 19.28 & 5.00 & 5.00 & 0.20 & 52.0 \\
\hline Deficient & Medium & $\mathrm{Ca}, \mathrm{Mg}, \mathrm{Na}$, high phosphate. . & 6.66 & 3.34 & 0.00 & 3.48 & 0.28 & 5.00 & 5.00 & 3.20 & 58.0 \\
\hline
\end{tabular}

- The phosphate was later increased to $0.5 \mathrm{me}$.

While insufficient data are available to afford a final answer to this question, the evidence at hand indicates that potassium deficiency in citrus, whether in seedlings, cuttings, or trees, is marked by a very narrow and consistent range of leaf values for potassium. For purposes of perspective, it should be stated at the outset that potassium values in citrus leaves range all the way from a low of 0.06 per cent to a high of over 9.0 per cent in the dry matter of the leaf. The latter figure was reported by Oppenheimer and Mendel (1938) for sweetlime seedlings injured from excessive potassium in the nutrient medium. Reed and Haas (1923b) reported values as high as 6.76 per cent, and in the authors' work values up to 4.85 per cent have been obtained in leaves of citrus plants injured by excessive potassium absorption. The 0.06 per cent low was found in sweet orange seedling leaves taken from plants grown in sand cultures markedly deficient in potassium.

In order first of all to show the relative constancy of potassium in the leaves of potassium-deficient sweet orange seedlings grown under a wide range of nutritional conditions, data taken from a former publication of Chapman and Brown (1943) are presented in table 14. The data show clearly that the symptoms of acute potassium deficiency were the same irrespective of nutrient conditions and the analysis of leaves of the same age and displaying the same kind of deficiency symptom (crinkling and malformation of leaves) showed substantially the same potassium content. The average value was 0.17 per cent; the lowest was 0.11 per cent, and the highest 0.25 per cent. Considering that potassium values in citrus leaves may range all the way from 0.06 to 9.0 per cent, the given values represent a narrow range. The lemon cuttings also included in the experiment and grown under the same nutrient conditions showed similar potassium levels in leaves from potassium-deficient plants.

The data of table 15 further substantiate the probability that values of less than 0.20 to 0.25 per cent potassium in citrus leaves (excluding senescent 


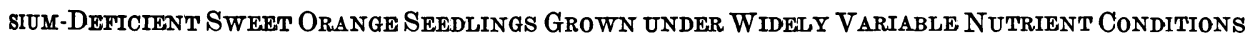

\begin{tabular}{|c|c|c|c|c|c|c|c|c|c|c|}
\hline \multicolumn{2}{|l|}{ Description of leaf } & \multicolumn{9}{|c|}{ Constituents of dry matter of leaf (per cent at $105^{\circ} \mathrm{C}$ ) } \\
\hline Color and condition & $\begin{array}{c}\text { Age } \\
\text { (months) }\end{array}$ & ash & $\mathrm{Ca}$ & $\mathbf{M g}$ & $\mathbf{K}$ & $\mathrm{Na}$ & $\mathrm{N}$ & $\mathbf{P}$ & $\mathbf{S}$ & $\mathrm{Cl}$ \\
\hline Yellowish, nitrogen deficient. . & 6 & 14.0 & 2.43 & 0.11 & 3.45 & 0.03 & 1.42 & 0.12 & 0.33 & 0.14 \\
\hline Green, normal.............. & 12 & 17.4 & 4.95 & 0.23 & 2.05 & 0.00 & 2.54 & 0.10 & & $\ldots$ \\
\hline 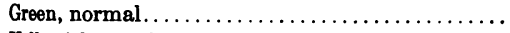 & 6 & 14.1 & 2.18 & 0.22 & 2.38 & 0.02 & 2.90 & 0.14 & 0.37 & 0.15 \\
\hline Yellowish, crinkled, acute potash deficiency..... & 6 & 11.9 & 3.72 & 0.52 & 0.11 & 0.06 & 2.47 & 0.12 & 0.36 & 0.13 \\
\hline Green, crinkled, acute potash deficiency ........ & 6 & 15.2 & 4.97 & 0.63 & 0.15 & $\cdots$ & 3.26 & 0.08 & $\ldots$ & $\ldots$ \\
\hline $\begin{array}{c}\text { Dull green, crinkled, yellow spots, acute potash } \\
\text { deficiency } \ldots \ldots \ldots \ldots \ldots \ldots \ldots\end{array}$ & 6 & 15.3 & 5.20 & 0.59 & 0.13 & 0.01 & 3.18 & 0.10 & 0.29 & 0.13 \\
\hline Yellowish, crinkled, acute potash deficiency.... & 6 & 10.2 & 2.74 & 0.62 & 0.17 & $\ldots$ & 3.16 & 0.12 & $\ldots$ & $\ldots$ \\
\hline Medium green, crinkled, acute potash deficiency & 6 & 12.3 & 5.02 & 0.61 & 0.25 & 0.40 & 3.02 & 0.12 & $\ldots$ & $\ldots$ \\
\hline Dull green, crinkled, acute potash deficiency..... & 6 & 15.65 & 5.17 & 0.57 & 0.19 & 0.02 & 3.30 & 0.12 & 0.35 & 0.07 \\
\hline Dull green, crinkled, acute potash deficiency.... & 6 & 16.55 & 5.60 & 0.67 & 0.20 & 0.01 & 3.66 & 0.15 & $\ldots$ & 0.40 \\
\hline Green, crinkled, acute potash deficiency........ & 6 & 13.60 & 4.35 & 0.55 & 0.16 & 0.15 & 3.30 & 0.11 & $\ldots$ & 0.34 \\
\hline Dull green, crinkled, acute potash deficiency.... & 6 & 17.35 & 5.84 & 0.60 & 0.16 & $\ldots$ & 3.22 & 0.20 & $\cdots$ & $\cdots$ \\
\hline
\end{tabular}

leaves about to absciss) are indicative of potassium deficiency within the plant as a whole. Assembled here are all the analyses known to the authors relating potassium in the leaf to known conditions as regards potassium status of the citrus plant. Data in lines 1 and 2 were drawn from sand culture experiments with young valencia trees on sour root carried out by Reed and Haas (1923a, 1923b). At the end of 16 months early symptoms of potassium deficiency were clearly manifest in the trees not receiving potassium. An analysis of a composite sample of all the leaves from one of these trees gave a value of 0.19 per cent. Data in lines 3 to 8 are from the experiment of Chapman and Brown (1943) previously referred to. As stated, the potassium value of leaves from both sweet orange and lemon plants showing severe deficiency symptoms ranged from 0.25 to 0.11 .

Data from the outdoor nutritional experiment on potassium with navel and valencia orange trees described by Chapman, Brown, and Rayner (1947) are presented in lines 9 to 14 . As stated previously, there were three groups of trees in this experiment: those amply supplied with potassium; those in which only the earliest stages of potassium deficiency were allowed to develop; and those allowed to become acutely deficient in this element. In the trees only slightly deficient, leaf values for potassium ranged from 0.26 to 0.35 per cent. In trees acutely deficient, values ranged from 0.14 to 0.24 .

Recently, Arnot of Australia (1947) reported on a sand culture experiment with young Washington navel orange trees in which characteristic symptoms of potassium deficiency developed on the trees not supplied with this element. Analyses of leaves from these trees showed values of 0.22 per cent potassium. Analyses of leaves from commercial orchards in Australia showing the same type of symptoms as those Arnot obtained in solution cultures showed values of 0.20 per cent. These two sets of data are given in lines 15-17. It is thus apparent that the reports of different workers show excellent agree- 


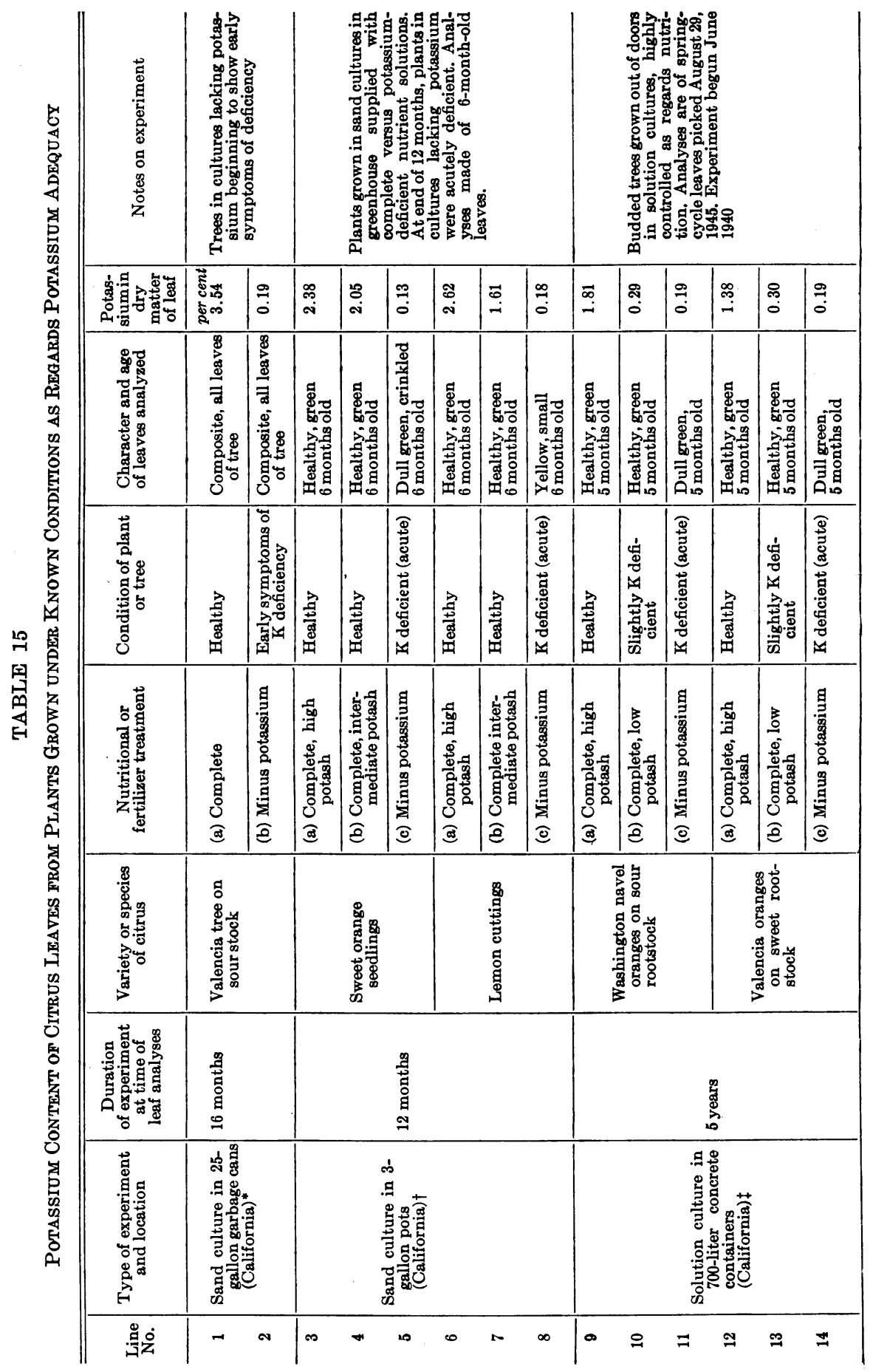




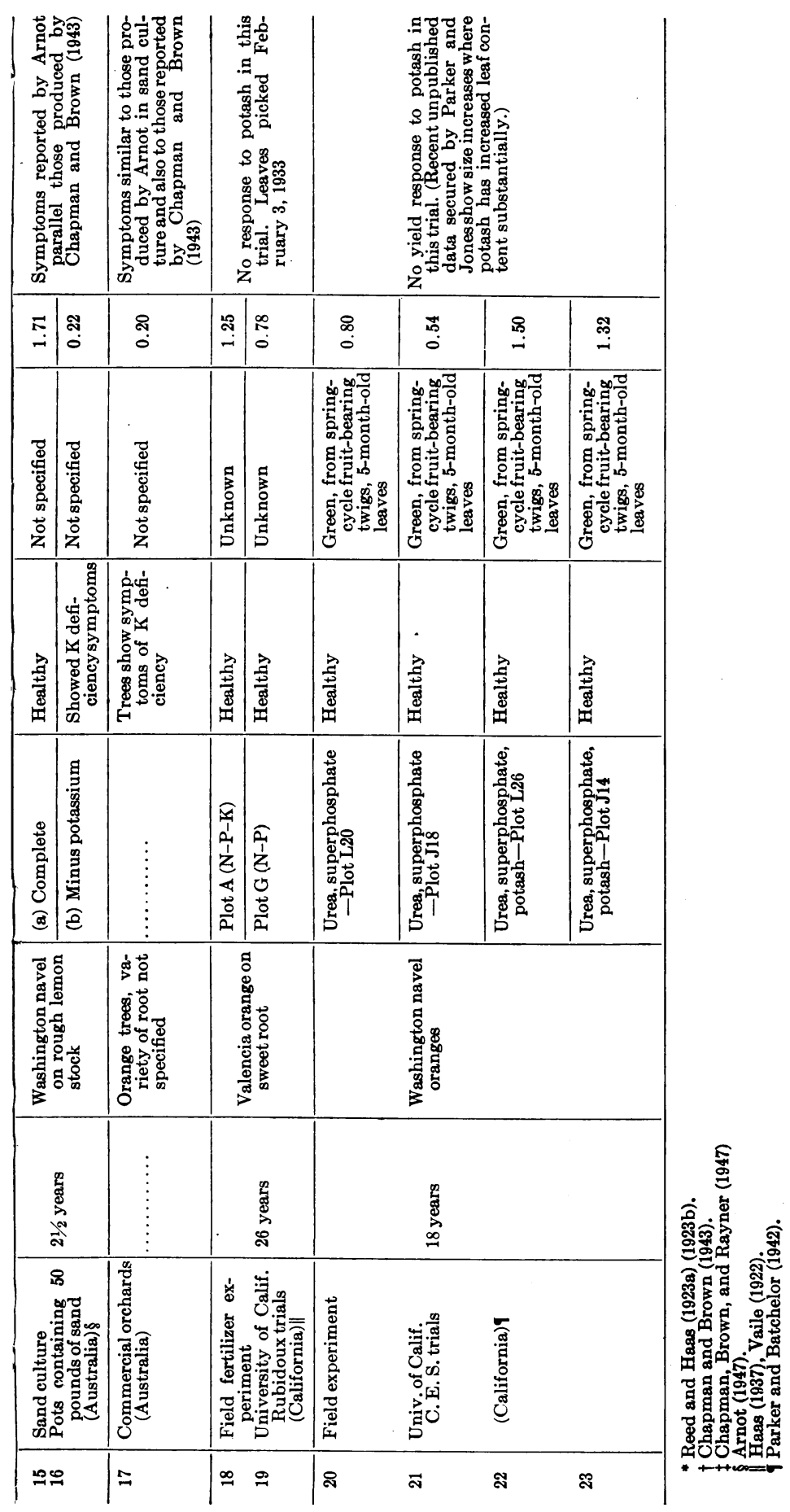




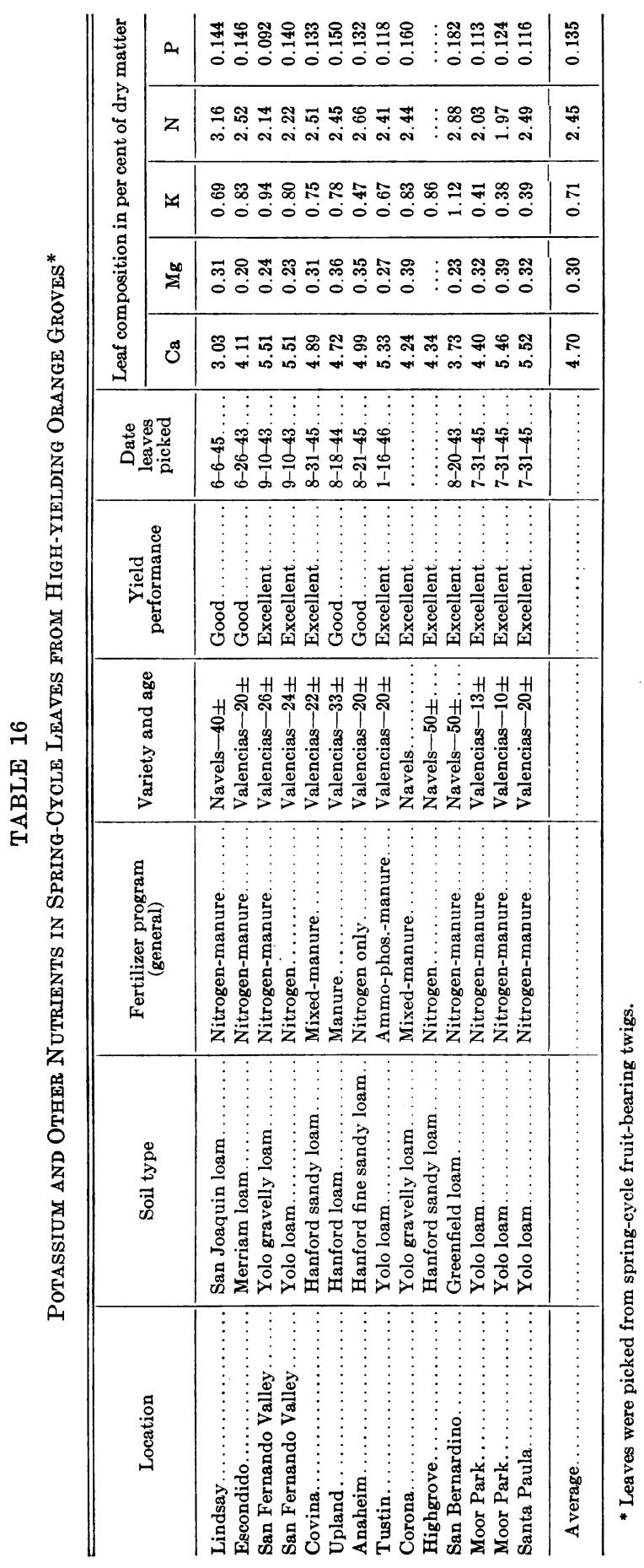


ment in leaf values for potassium where the citrus plant shows clearcut potassium-deficiency symptoms.

Also included in table 15 are leaf-analysis data from two longtime field fertilizer trials with citrus carried out by the University of California Citrus Experiment Station. In the earliest experiment, known as the Rubidoux experiment, enough different treatments were included to afford a fairly reliable estimate of potassium need, although the soil was not altogether uniform and

\section{TABLE 17}

Leaf ANalysis Standards and Other Criteria for Assessing Potassium Status of Orange Trees

\begin{tabular}{|c|c|c|c|}
\hline $\begin{array}{l}\text { Potassium in } \\
\text { dry matter of } 3-\text { to } \\
7 \text {-month-old leaves } \\
\text { from } \\
\text { fruit-bearing twigs }\end{array}$ & $\begin{array}{l}\text { Indications as to } \\
\text { potassium status } \\
\text { of tree }\end{array}$ & $\begin{array}{l}\text { Other criteria helpful in diagnosis, and } \\
\text { associated conditions to look for }\end{array}$ & $\begin{array}{l}\text { Probability of } \\
\text { yield response } \\
\text { to application } \\
\text { of adequate } \\
\text { potash fertilizer }\end{array}$ \\
\hline $\begin{array}{c}\text { per cent } \\
\text { Less than } 0.25\end{array}$ & $\begin{array}{l}\text { Potassium likely } \\
\text { deficient }\end{array}$ & $\begin{array}{l}\text { Look for crinkled, puckered leaves, more or less } \\
\text { yellowing of foliage, excessive leaf shedding at } \\
\text { bloom period, small fruit ard dieback of twigs, } \\
\text { excessive sunburn on south side of tree follow- } \\
\text { ing hot weather }\end{array}$ & Good \\
\hline $0.25-0.40$ & $\begin{array}{l}\text { Potassium may be } \\
\text { slightly deficient }\end{array}$ & $\begin{array}{l}\text { Look for heavier than usual shedding of leaves at } \\
\text { bloom period, small fruit; leaves may show un- } \\
\text { usual amount of sunburn on south side follow- } \\
\text { ing hot weather }\end{array}$ & Fair \\
\hline $0.40-1.00$ & $\begin{array}{l}\text { Potassium prob- } \\
\text { ably ample }\end{array}$ & $\begin{array}{l}\text { This is the range of potash values found in } \\
\text { healthy high-yielding orchards; if orchard not } \\
\text { productive look for causes other than potash } \\
\text { deficiency or excess }\end{array}$ & $\begin{array}{l}\text { Very doubtful } \\
\text { (fruit sizes, how- } \\
\text { ever, may be in- } \\
\text { creased by potash } \\
\text { in this range) }\end{array}$ \\
\hline $1.00-2.50$ & Potassium ample & $\begin{array}{l}\text { Look for other deficiencies or conditions limiting } \\
\text { tree growth }\end{array}$ & $\begin{array}{l}\text { None (doubtful ef- } \\
\text { fect on fruit size) }\end{array}$ \\
\hline
\end{tabular}

plot replication was not such as to permit evaluation of small differences. No evidence of a response to potassium was obtained in this experiment; leaf analyses made of valencia leaves from one of the plots receiving nitrogen and phosphorus but no potash showed 0.78 per cent potassium, a value well above those associated with a deficiency of this element.

The other fertilizer trial located on the present Citrus Experiment Station grounds likewise has given negative results with potassium (Parker and Batchelor, 1942). Leaves from trees in plots receiving nitrogen and phosphorus but no potassium showed values ranging from 0.54 to 0.80 per cent in five-month-old spring-cycle leaves from fruit-bearing twigs. Recent data emanating from this experiment, as reported by Parker and Jones (unpublished) show evidence of fruit size improvements where potash applications have appreciably raised the potassium content of the leaves. 
Not included in table 15 are leaf-analysis data from a number of other fertilizer experiments of shorter duration being carried out in numerous commercial groves. None of these trials has thus far shown evidence of response to potash applications. The leaf values for potassium in trees of plots receiving nitrogen and phosphorus but no potassium range, as among these different groves, from 0.42 to 1.46 per cent potassium in five-month-old spring-cycle leaves from fruit-bearing branches.

Table 16 presents further evidence suggesting that values greater than 0.40 indicate an ample potassium supply. The group of high-yielding commercial orange groves in California gave leaf-analysis data showing potassium values ranging from 0.38 to 1.12 per cent.

Based on the evidence available, a series of leaf-analysis standards for potassium are presented in table 17. These values are thought to hold for both valencia and navel orange trees irrespective of rootstock. They may also hold reasonably well for lemons though further testing will be necessary to confirm this. It should be emphasized that these standards apply only to leaves taken from fruit-bearing (and probably nonfruit-bearing; see page 509) spring-cycle twigs during the period July through November; i.e., leaves varying from three to seven months of age. Young tender leaves and senescent leaves are likely to give wholly misleading information if potassium status is judged by the standards in table 17.

Satisfactory techniques for sampling, handling, and analyzing the leaves are set forth in the following section.

\section{STUDIES OF SAMPLING TECHNIQUE}

In the course of our studies on leaf analysis many different tests were made of analytical methods, methods of cleaning leaves, and sampling techniques. The more significant of the data and results are here given.

\section{Analysis and Cleaning Methods}

With reference to the method of analyzing leaves for total potassium, a comparison of the cobaltinitrite method as outlined by Wilcox (1937), and the standard platinic chloride method gave identical average values on a series of 34 different samples. The potassium percentage of these various samples ranged from 0.30 to 0.93 per cent. The average for the cobaltinitrite method was 0.578 per cent and for the platinic chloride method 0.577 per cent. As between replicate determinations of potassium by the cobaltinitrite method on ground samples from the same bottle, the maximum variation between the highest and the lowest value was about 5 per cent.

With regard to cleaning leaves prior to drying, grinding, and analysis, several techniques were compared. In one experiment a large sample of about 300 orange leaves freshly picked was divided in half, and one set was cleaned by wiping each leaf with a damp cloth, while the other was washed by sloshing the leaves en masse with tapwater in a large pan, using several changes of water and finally rinsing with distilled water. The average of duplicate determination gave a value of 1.155 per cent for the wiping technique and 1.160 for the washing en masse.

In another experiment comparison was made between washing en masse, 
as in the former test, and washing each leaf separately. In the latter method, each leaf was washed with the fingers in a stream of tapwater and then rinsed with distilled water. The results on eight different sets of samples, shown in table 18, indicate no difference between washing methods.

The data suggest that no potassium is lost by thorough washing of fresh leaves in water. However, in view of the fact that a large part of the total

TABLE 18

Effect of Method of Cleaning Orange Leaves on Potash Content

\begin{tabular}{|c|c|c|}
\hline \multirow[b]{2}{*}{ Sample no. } & \multicolumn{2}{|c|}{ Per cent potassium in dry matter } \\
\hline & $\begin{array}{l}\text { Each leaf } \\
\text { washed } \\
\text { separately }\end{array}$ & $\begin{array}{l}\text { Leaves sloshed } \\
\text { about in beaker } \\
\text { with several } \\
\text { changes of water }\end{array}$ \\
\hline $2198 \ldots \ldots \ldots \ldots \ldots$ & .58 & .57 \\
\hline $2199 \ldots \ldots$ & .58 & .57 \\
\hline $2200 \ldots$ & .63 & .64 \\
\hline $2201 \ldots$ & .59 & .58 \\
\hline 2202. & .58 & .54 \\
\hline $2203 \ldots$ & .62 & .64 \\
\hline $2204 \ldots \ldots \ldots \ldots \ldots \ldots \ldots$ & .40 & .39 \\
\hline 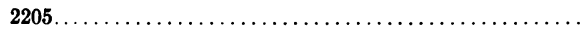 & .60 & .62 \\
\hline Average $\ldots \ldots \ldots \ldots \ldots \ldots \ldots \ldots \ldots \ldots \ldots \ldots \ldots$ & .572 & .568 \\
\hline
\end{tabular}

TABLE 19

Effect of Drying Technique on Potash Percentage in Citrus Leaves*

\begin{tabular}{|c|c|}
\hline Method of drying chopped-up green leaves & $\begin{array}{l}\text { Potassium in } \\
\text { dry matter- } \\
\qquad 105^{\circ} \mathrm{C} \dagger\end{array}$ \\
\hline $\begin{array}{l}\text { Allowed to air-dry in open evaporating dish } 6 \text { days; then put in oven at } 105^{\circ} \mathrm{C} \text { for } 24 \text { hours. } \\
\text { Potassium determined on this }\end{array}$ & \\
\hline $\begin{array}{l}\text { Potassium determined on this sample } \\
\text { Dried at } 50^{\circ} \mathrm{C} \text { for } 24 \text { hours; loss at } 105^{\circ} \mathrm{C} \text { determined on separate sample and result computed } \\
\text { to } 105^{\circ} \mathrm{C} \text { basis } \ldots \ldots \ldots \ldots \ldots \ldots \ldots \ldots \ldots \ldots \ldots \ldots \ldots \ldots\end{array}$ & 1.05 \\
\hline Dried at $50^{\circ} \mathrm{C}$ for 24 hours; then dried in oven at $105^{\circ} \mathrm{C}$ for 24 hours and analyzed for potassium & 1.06 \\
\hline Dried at $50^{\circ} \mathrm{C}$ for 72 hours; then dried in oven at $105^{\circ} \mathrm{C}$ for 24 hours and analyzed for potassium & 1.08 \\
\hline Dried at $80^{\circ} \mathrm{C}$ for 24 hours; then dried in oven at $105^{\circ} \mathrm{C}$ for 24 hours and analyzed for potassium & 1.05 \\
\hline
\end{tabular}

- Green sample of navel leaves chopped in food chopper and handled as above.

$\dagger$ Average of duplicate determinations:

potassium in citrus leaves is water-soluble, and since it is not always feasible to deal with strictly fresh samples, use of the leaf-wiping technique is recommended. Clean diaper cloth has been found useful for the purpose.

Another question arising during the course of the work was whether the method of drying the leaves prior to analysis would affect percentage composition. For this experiment a large sample of fresh navel orange leaves was first washed and then ground into coarse pieces in a food chopper. The ground fresh material was then thoroughly mixed and divided into five lots. These lots were dried in various ways (see table 19) and analyzed for potassium, the results being expressed as percentage total potassium in dry matter at $105^{\circ} \mathrm{C}$. No significant differences were found. 


\section{Experiments on Sampling Techniques}

A considerable number of questions additional to those of leaf age, cycle, etc., naturally arose in arriving at a final sampling procedure. Among these were whether leaves from one part of the tree varied from those taken from

TABLE 20

Inorganic Composition of Leaves Picked from Top, Middle, and Lower Part of Tree*

\begin{tabular}{|c|c|c|c|c|c|c|c|c|}
\hline \multirow{2}{*}{$\begin{array}{c}\text { Sample } \\
\text { no. }\end{array}$} & \multirow{2}{*}{ Part of tree } & \multicolumn{7}{|c|}{ Composition in per cent of dry matter } \\
\hline & & $\mathbf{C a}$ & $\mathbf{M g}$ & $\mathbf{K}$ & $\mathbf{N}$ & $\mathbf{P}$ & $\mathbf{S}$ & $\mathrm{Cl}$ \\
\hline 5903 & Top- $10^{\prime}-16^{\prime}$ from ground... & 2.44 & .27 & 1.19 & 1.92 & .174 & .22 & .09 \\
\hline 5904 & Middle $-5^{\prime}-10^{\prime}$ from ground. & 2.39 & .25 & 1.25 & 2.50 & .178 & .26 & .09 \\
\hline 5905 & Bottom $-2^{\prime}-5^{\prime}$ from ground. & 2.36 & .23 & 1.25 & 2.64 & .185 & .22 & .07 \\
\hline
\end{tabular}

* Each sample consisted of about 200 leaves picked from the 8 trees of plot I36; they were taken from springcycle twigs on June $27,1945$.

TABLE 21

Potassium Content of Leades Picked from Top to Bottom Segments Around Tree*

\begin{tabular}{|c|c|c|}
\hline \multirow{2}{*}{ Segment no.† } & \multicolumn{2}{|c|}{$\begin{array}{l}\text { Per cent potassium in dry matter } \\
\text { of a } 25 \text {-leaf composite }\end{array}$} \\
\hline & $\begin{array}{l}\text { Plot F32 } \\
\text { (urea) }\end{array}$ & $\begin{array}{c}\text { Plot K12 } \\
\text { (manure cover } \\
\text { crop) }\end{array}$ \\
\hline 1 (slightly east of north)...... & $\begin{array}{l}\text { per cent } \\
0.70\end{array}$ & $\begin{array}{l}\text { per cent } \\
1.24\end{array}$ \\
\hline $2 \ldots \ldots \ldots \ldots \ldots \ldots \ldots \ldots$ & 0.71 & 1.25 \\
\hline 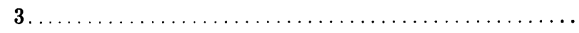 & 0.74 & 1.21 \\
\hline 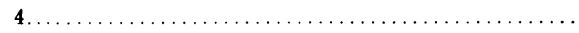 & 0.73 & 1.21 \\
\hline$\ldots \ldots \ldots \ldots \ldots \ldots \ldots \ldots \ldots \ldots$ & 0.67 & 1.20 \\
\hline $6 \ldots \ldots \ldots \ldots \ldots \ldots \ldots \ldots \ldots \ldots \ldots \ldots \ldots \ldots \ldots \ldots \ldots$ & 0.75 & 1.28 \\
\hline 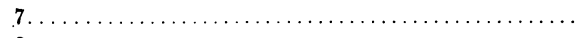 & 0.75 & 1.20 \\
\hline 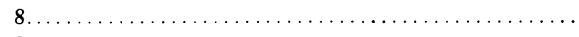 & 0.74 & 1.26 \\
\hline 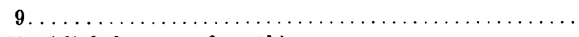 & 0.74 & 1.26 \\
\hline 10 (slightly west of north) $\ldots \ldots \ldots \ldots \ldots \ldots \ldots \ldots$ & 0.72 & 1.20 \\
\hline
\end{tabular}

* Leaves collected June 1945 from spring-cycle twigs.

$\dagger$ Each of these 10 samples was taken from different segments of the same tree.

another part; the differences, if any, between large and small leaves; individual tree variation; and variability of samples taken from different parts of the same orchard.

To determine the variability in inorganic composition of leaves picked from various parts of the same tree, a composite sample of leaves taken from the tops, middle, and lower portions respectively of a group of trees in one of the Citrus Experiment Station fertilizer plots (plot I36) were collected. Each composite sample consisted of about 200 leaves. These were spring-cycle leaves from fruit-bearing twigs. The results (table 20) indicate that the leaves from the tops of the trees are definitely lower in nitrogen, and slightly lower in potassium and phosphorus although differences in the case of these two ele- 
ments are slight. Calcium and magnesium appear to be slightly higher in the top leaves.

Two tests were made to find out whether the leaves on different sides of the tree vary in composition. In the first test a composite sample of 25 leaves was taken from spring-cycle fruit- and nonfruit-bearing twigs from the bottom to the top of the tree at ten different stations around a single tree. The results, shown in table 21, indicate no constant trend. The second test was made of leaves taken respectively from the north, east, south, and west sides of the tree. Each sample was a composite of leaves taken from the fertilizer plot

TABLE 22

Inorganic Composition of Leaves Picked from Four Different Sides of Tree

\begin{tabular}{|c|c|c|c|c|c|c|c|c|}
\hline \multirow{2}{*}{$\begin{array}{l}\text { Sample } \\
\text { no.* }\end{array}$} & \multirow{2}{*}{$\begin{array}{c}\text { Side of } \\
\text { tree }\end{array}$} & \multicolumn{7}{|c|}{ Composition in per cent of dry matter } \\
\hline & & $\mathrm{Ca}$ & Mg & $\mathrm{K}$ & $\mathrm{N}$ & $\mathbf{P}$ & $\mathbf{S}$ & $\mathrm{Cl}$ \\
\hline 5895 & North. & $\begin{array}{c}\text { per cent } \\
2.26\end{array}$ & $\begin{array}{c}\text { percent } \\
.23\end{array}$ & $\begin{array}{c}\text { percent } \\
1.34\end{array}$ & $\begin{array}{c}\text { per cent } \\
2.73\end{array}$ & $\begin{array}{c}\text { percent } \\
.174\end{array}$ & $\begin{array}{c}\text { percent } \\
.25\end{array}$ & $\begin{array}{c}\text { percent } \\
.08\end{array}$ \\
\hline 5896 & East. . & 2.31 & .25 & 1.40 & 2.72 & .178 & .22 & .10 \\
\hline 5897 & South.. & 2.72 & .25 & 1.33 & 2.72 & .182 & .21 & .11 \\
\hline 5898 & West.... & 2.75 & .24 & 1.29 & 2.72 & .190 & .25 & .09 \\
\hline
\end{tabular}

* Each sample is a composite of spring-cycle leaves from 8 trees of plot I36. Picked June 21, 1945.

TABLE 23

Inorganic Composition of Large vs. Small Leaves

\begin{tabular}{c|c|c|c|c|c|c|c|c}
\hline \hline \multirow{2}{*}{$\begin{array}{c}\text { Sample } \\
\text { no.* }\end{array}$} & $\begin{array}{c}\text { Size of } \\
\text { leaves }\end{array}$ & \multicolumn{8}{c}{ Composition in per cent of dry matter } \\
\cline { 3 - 8 } & & $\mathrm{Ca}$ & $\mathrm{Mg}$ & $\mathrm{K}$ & $\mathrm{N}$ & $\mathrm{P}$ & $\mathrm{S}$ & $\mathrm{Cl}$ \\
\hline 5899 & Large........ & 2.51 & .22 & 1.36 & 2.68 & .186 & .23 & .08 \\
5900 & Small....... & 2.66 & .25 & 1.31 & 2.57 & .184 & .23 & .11 \\
\hline
\end{tabular}

* Each sample is a composite of about 200 spring-cycle leaves picked from 8 trees of plot I36. About 25 leaves taken from each tree in a band around circumference at a height of from 2 to 7 feet from ground. Picked June 21, 1945 .

sampled, and consisted of about 200 leaves. The leaves were spring-cycle from both fruit- and nonfruit-bearing twigs taken from the middle portions of the tree (zone 2 to 7 feet from ground). The results are shown in table 22 . There appears to be no significant difference save in the case of calcium. The leaves from the south and west sides of the tree are a little higher in this element.

While leaves from spring-cycle twigs average smaller in size than those from other growth cycles, there are among these great variations in size. Some, especially those on the southerly side of the tree, are often very small as compared with leaves from the north side. The question thus arose whether inorganic composition is materially influenced by leaf size. Composite samples respectively of small and large leaves were collected from a total of eight trees in the same fertilizer plot as that of the preceding experiment. The results, given in table 23 , reveal only a very small and doubtful difference in inorganic composition.

Another question of interest was as to individual tree variation. 'To test this 
question, leaf samples were obtained from each of four trees in two different fertilizer plots. Forty leaves were picked from each tree. These trees were sampled at successive months over a period of six months (June through November). The data, shown in table 24 , reveal good tree uniformity, withas might be expected-a moderate degree of variability. This suggests that, in obtaining leaves for advisory purposes, sampling and compositing from five or more trees at most will suffice to secure an average figure representing potassium status in the part of the grove in question.

To determine the variation between successive composite samples of leaves taken from the same trees of an orchard, a set of ten samples was procured. Each sample consisted of 15 leaves taken in a band from two to seven feet above ground around each of ten consecutive trees. The leaves were picked from spring-cycle fruit-bearing twigs in September 1945, five of the composite samples by one operator and five by another. The leaves, washed individually and dried at $50^{\circ} \mathrm{C}$, were analyzed for calcium, magnesium, potassium, nitrogen, and phosphorus. The results (table 25) show, as might be expected from previous data, that the variability between samples and that between the sample-groups of the two operators agree closely.

The preceding information indicates that the potassium status of any particular part of an orchard can be ascertained, within the limitations of the leaf-analysis method, by compositing 15 to 20 representative leaves from each of five to ten representative trees in that particular part of the orchard. The succeeding question is to determine the variations in potassium status of groups of trees in widely different parts of the same orchard. To this end, composite leaf samples were procured from replicate plots of the Citrus Experiment Station fertilizer trials. This whole experiment covers an area of about 50 acres, and so far as general management is concerned (i.e. irrigation, pest control, etc.) is treated uniformly. Each fertilizer treatment is replicated four times and in general the replicates are widely scattered. Each plot consists of eight trees. In September 1945 composite leaf samples from eight trees of each of the four replicate plots were collected from fruit-bearing springcycle twigs. The leaves were washed individually, dried at $50^{\circ} \mathrm{C}$, and analyzed for calcium, magnesium, potassium, nitrogen, and phosphate.

The results, shown in table 26 , indicate that while for the most part there was a considerable uniformity of potassium status in similarly treated plots, the differences between replicate plots in some instances exceed sampling error and suggest soil differences. Similar differences have sometimes been obtained in the sampling of commercial orchards.

All of this suggests that the best way to make a detailed evaluation of the potassium status of commercial orchards is to secure composite samples of from 15 to 20 leaves each, from five or more representative trees in each of several parts of an orchard. If less detailed knowledge is required, one composite sample taken from one representative tree in five or more widely separated locations will suffice.

\section{DISCUSSION}

It may be remarked that the investigation reported in this paper leaves certain aspects untouched or incomplete. For example, no attempt was made to determine whether water-soluble or some other fraction might be a better 
indicator of potassium status than total potassium. Further, a more exhaustive investigation of the plant part best suited might have been carried out, and more complete studies on the relation of fruiting behavior to potassium status. But in the light of the information obtained, it seemed, to the authors, that the leaf was sufficiently sensitive to potassium variations in the nutrient medium. This question, and the question of the most satisfactory type and age of leaf once settled, the important problem is whether the tentative levels established for incipient and acute potassium deficiency are basic, and hold under all conditions in which citrus is grown.

The data thus far accumulated suggest that the values presented in table 17 are fundamental; but it will require further data from field experiments in various parts of the world to fully confirm these tentative standards: Moreover, the extent to which and under what conditions the quality or size of fruit can be influenced by marked increases in potassium above critical levels are not known. Our work thus far (Chapman, Brown, and Rayner, 1947) indicates that increases in potassium above the level required for optimum yields will make fruit slightly more acid, increase rind coarseness somewhat, and may increase fruit size. Parker and Jones (unpublished data) have recently found in a field experiment that substantial increases in the potassium of leaves have somewhat increased fruit sizes.

Meanwhile, a tentative set of standard values and a workable method (see Appendix for details of sampling analysis) are presented for all who are engaged in citrus research to test under their particular set of conditions. The authors again emphasize that where some other nutrient or growth factor is more limiting than potassium, potassium in all probability will be found in amounts deemed ample or even excessive. The situation with respect to potassium adequacy may be entirely different, however, when the other limiting conditions are corrected. On the basis of present knowledge and experience it is impossible to forecast what the potassium status will be when other limiting conditions are corrected.

With reference to the use of nutrient ratios as a basis for diagnosis, or the use of both ratio and concentration as suggested by Shear, Crane, and Myers (1948), the authors have felt that little if anything is to be gained so far as specific potassium diagnosis is concerned, particularly when all the available evidence indicates that total potassium on a percentage-dry-matter basis correlates well with potassium status. The data of table 14 in fact indicate that the ratio of potassium to one or more other mineral constituents in the leaf correlates less well with potassium status than potassium percentage alone. Some other basis of evaluation may well prove better suited in the case of phosphorus, nitrogen, calcium, or magnesium.

In evaluating potassium status it is worth while, though not essential, to make analyses for calcium, magnesium, nitrogen, phosphorus, and sulfur. This supplementary information may offer clues as to why potassium is high or low, and also give preliminary indication about the nutrient status of these other elements. In all cases where the deficiency of any of these elements is acute, it is known that leaf content of the element is subnormal.

The percentage composition of three- to seven-month-old spring-cycle leaves associated with, or suggestive of incipient deficiency of each of the nutrient 
TABLE 24

Variation in Percentage Potassium of Composite Sample of Leaves From Individual Trees in Fertilizer Plots*

\begin{tabular}{|c|c|c|c|c|c|c|c|c|c|}
\hline \multirow{2}{*}{ Date sampled } & \multirow{2}{*}{$\begin{array}{c}\text { Age of } \\
\text { leaf } \\
\text { (months) }\end{array}$} & \multicolumn{4}{|c|}{$\begin{array}{c}\text { Plot F } 38 \dagger \\
\text { (urea-no cover crop) }\end{array}$} & \multicolumn{4}{|c|}{$\begin{array}{c}\text { Plot } \mathrm{J} 16 \dagger \\
\text { (urea, } \mathrm{P}_{2} \mathrm{O}_{5}, \mathrm{~K}_{2} \mathrm{O}, \text { manure } \times 3 \text { ) }\end{array}$} \\
\hline & & Tree 2 & Tree 4 & Tree 6 & Tree 8 & Tree 2 & Tree 4 & Tree 6 & Tree 8 \\
\hline $6-8-43$ & 3 & 0.85 & 0.69 & 0.76 & 0.61 & 1.18 & 1.09 & 1.33 & 1.09 \\
\hline $7-6-43$ & 4 & 0.58 & 0.58 & 0.60 & 0.57 & 1.09 & 1.05 & 1.40 & 1.30 \\
\hline $8-6-43$. & 5 & 0.53 & 0.61 & 0.69 & 0.52 & 1.13 & 1.10 & 1.24 & 1.27 \\
\hline $9-2-43$. & 6 & 0.62 & 0.64 & 0.66 & 0.63 & 1.12 & 1.20 & 1.12 & 1.03 \\
\hline $10-4-43 \ldots$ & 7 & 0.54 & 0.56 & 0.57 & 0.53 & 0.96 & 1.03 & 0.89 & 0.75 \\
\hline $11-5-43 \ldots \ldots \ldots \ldots \ldots \ldots \ldots \ldots$ & 8 & 0.60 & 0.51 & 0.52 & 0.65 & 0.61 & 0.89 & 0.64 & 0.67 \\
\hline Mean $\ldots \ldots \ldots \ldots \ldots$ & . & 0.62 & 0.60 & 0.63 & 0.58 & 1.01 & 1.06 & 1.10 & 1.02 \\
\hline
\end{tabular}

* 40 leaves from each of the trees were collected. The leaves were spring-cycle from fruit-bearing twigs taken in a band around circumference of tree.

$\dagger$ The averages of the figures for individual trees are used in table 5.

TABLE 25

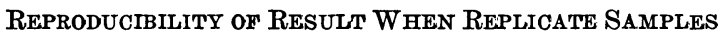
TAKen From SAME Group of Trees

\begin{tabular}{|c|c|c|c|c|c|c|}
\hline \multirow{2}{*}{$\begin{array}{c}\text { Sample } \\
\text { no.* }\end{array}$} & \multirow{2}{*}{ Collector } & \multicolumn{5}{|c|}{ Composition in per cent dry matter } \\
\hline & & $\mathrm{Ca}$ & $\mathrm{Mg}$ & $\mathbf{K}$ & $\mathrm{N}$ & $\mathbf{P}$ \\
\hline 4685 & $\mathbf{A} \ldots \ldots \ldots \ldots \ldots$ & 3.78 & 0.22 & 1.07 & 2.75 & 0.147 \\
\hline 4686 & A... & 3.66 & 0.22 & 1.08 & 2.80 & 0.149 \\
\hline 4687 & A.... & 3.69 & 0.21 & 1.10 & 2.80 & 0.148 \\
\hline 4688 & A........ & 3.73 & 0.22 & 1.07 & 2.76 & 0.152 \\
\hline 4689 & A......... & 3.62 & 0.20 & 1.10 & 2.80 & 0.152 \\
\hline Av. & $\ldots \ldots \ldots \ldots \ldots$ & 3.70 & 0.21 & 1.08 & 2.78 & 0.150 \\
\hline 4690 & B. . & 3.80 & 0.23 & 1.06 & 2.85 & 0.148 \\
\hline 4691 & B............ & 3.68 & 0.22 & 1.07 & 2.87 & 0.152 \\
\hline 4692 & $\mathbf{B} \ldots \ldots \ldots \ldots$ & 3.76 & 0.22 & 1.10 & 2.85 & 0.149 \\
\hline 4693 & $\mathbf{B} \ldots \ldots \ldots \ldots \ldots$ & 3.80 & 0.21 & 1.15 & 2.83 & 0.152 \\
\hline 4694 & B.......... & 3.72 & 0.20 & 1.12 & 2.76 & 0.156 \\
\hline Av. & & 3.75 & 0.22 & 1.10 & 2.83 & 0.151 \\
\hline Mean... & & 3.72 & 0.21 & 1.09 & 2.81 & 0.150 \\
\hline Range & . & $3.62-3.80$ & $20-23$ & $1.06-1.15$ & $2.75-2.87$ & $.147-.156$ \\
\hline
\end{tabular}

* Each sample consisted of 150 leaves, taken from the same 10 trees. 15 leaves were collected per tree in a band around circumference of tree. Leaves were collected on September 18, 1943 from spring-cycle fruit-bearing twigs. No effort was made to collect each successive replicate from the same twigs.

elements in turn is given in column 2 of table 27. It should be emphasized that all data in this table represent tentative values, and while based on the best information available are obviously incomplete and should be regarded as of guidance value only. Columns 3 and 4 give the range and average values for similarly aged leaves found in high-performance groves. Column 5 gives tentative values for each element associated with or suggestive of unbalanced nutrient conditions in the tree. In the remaining columns are shown, so far 
TABLE 26

VARIABILITY OF RESUlts When SAMPLES COLLECTED From Different Parts of 50-Acre Planting*

\begin{tabular}{|c|c|c|c|c|c|c|}
\hline \multirow{2}{*}{ Plot treatment } & \multirow{2}{*}{ Plot no. } & \multicolumn{5}{|c|}{ Composition in per cent of dry matter } \\
\hline & & $\mathbf{C a}$ & $\mathbf{M g}$ & $\mathbf{K}$ & $\mathrm{N}$ & $\mathbf{P}$ \\
\hline Urea, cover crop................. & $\begin{array}{l}\text { M12 } \\
\text { F50 } \\
\text { I6 } \\
\text { K28 }\end{array}$ & $\begin{array}{l}5.05 \\
5.02 \\
4.94 \\
4.64\end{array}$ & $\begin{array}{l}0.40 \\
0.36 \\
0.41 \\
0.36\end{array}$ & $\begin{array}{l}0.68 \\
0.70 \\
0.71 \\
0.88\end{array}$ & $\begin{array}{l}2.95 \\
2.66 \\
2.83 \\
2.90\end{array}$ & $\begin{array}{l}0.124 \\
0.103 \\
0.112 \\
0.122\end{array}$ \\
\hline Factory Mix 3-3-3, cover crop........ & $\begin{array}{l}\text { M26 } \\
\text { D6 } \\
\text { I10 }\end{array}$ & $\begin{array}{l}4.57 \\
5.07 \\
4.96\end{array}$ & $\begin{array}{l}0.33 \\
0.33 \\
0.34\end{array}$ & $\begin{array}{l}1.08 \\
1.09 \\
1.02\end{array}$ & $\begin{array}{l}3.03 \\
2.91 \\
2.88\end{array}$ & $\begin{array}{l}0.131 \\
0.130 \\
0.118\end{array}$ \\
\hline Nitrate of lime, cover crop $\ldots \ldots \ldots \ldots$ & $\begin{array}{l}\text { L12 } \\
\text { O32 } \\
\text { H24 } \\
\text { I40 }\end{array}$ & $\begin{array}{l}5.25 \\
5.55 \\
5.25 \\
5.03\end{array}$ & $\begin{array}{l}0.40 \\
0.37 \\
0.41 \\
0.39\end{array}$ & $\begin{array}{l}0.63 \\
0.74 \\
0.72 \\
0.81\end{array}$ & $\begin{array}{l}2.86 \\
2.80 \\
2.95 \\
2.84\end{array}$ & $\begin{array}{l}0.124 \\
0.122 \\
0.127 \\
0.130\end{array}$ \\
\hline Urea, superphosphate, sulfate of potash, cover crop..... & $\begin{array}{l}\text { L18 } \\
\text { J10 } \\
\text { E14 } \\
\text { I42 }\end{array}$ & $\begin{array}{l}4.64 \\
4.78 \\
4.91 \\
4.62\end{array}$ & $\begin{array}{l}0.37 \\
0.36 \\
0.36 \\
0.37\end{array}$ & $\begin{array}{l}1.09 \\
0.90 \\
1.05 \\
1.24\end{array}$ & $\begin{array}{l}2.81 \\
2.83 \\
2.98 \\
2.94\end{array}$ & $\begin{array}{l}0.124 \\
0.118 \\
0.120 \\
0.128\end{array}$ \\
\hline Urea, superphosphate, cover crop............ & $\begin{array}{l}\text { L20 } \\
\text { J18 } \\
\text { E12 } \\
\text { H46 }\end{array}$ & $\begin{array}{l}5.01 \\
4.84 \\
5.34 \\
4.80\end{array}$ & $\begin{array}{l}0.40 \\
0.37 \\
0.40 \\
0.41\end{array}$ & $\begin{array}{l}0.80 \\
0.54 \\
0.71 \\
0.90\end{array}$ & $\begin{array}{l}2.90 \\
2.75 \\
2.99 \\
2.92\end{array}$ & $\begin{array}{l}0.122 \\
0.105 \\
0.120 \\
0.124\end{array}$ \\
\hline Urea, superphosphate, sulfate of potash, cover crop...... & $\begin{array}{l}\text { L26 } \\
\text { J14 } \\
\text { E2 } \\
\text { H40 }\end{array}$ & $\begin{array}{l}4.26 \\
4.31 \\
4.78 \\
4.50\end{array}$ & $\begin{array}{l}0.32 \\
0.33 \\
0.27 \\
0.33\end{array}$ & $\begin{array}{l}1.50 \\
1.32 \\
1.23 \\
1.23\end{array}$ & $\begin{array}{l}2.85 \\
2.88 \\
2.77 \\
2.92\end{array}$ & $\begin{array}{l}0.123 \\
0.120 \\
0.116 \\
0.122\end{array}$ \\
\hline Manure, cover crop $\ldots \ldots \ldots \ldots \ldots \ldots \ldots \ldots \ldots$ & $\begin{array}{l}\text { M34 } \\
\text { K16 } \\
\text { I36 }\end{array}$ & $\begin{array}{l}4.66 \\
4.62 \\
4.79\end{array}$ & $\begin{array}{l}0.32 \\
0.32 \\
0.33\end{array}$ & $\begin{array}{l}1.59 \\
1.50 \\
1.48\end{array}$ & $\begin{array}{l}2.77 \\
2.66 \\
2.74\end{array}$ & $\begin{array}{l}0.121 \\
0.116 \\
0.114\end{array}$ \\
\hline Urea, sulfate of potash, cover crop............... & $\begin{array}{l}\text { E6 } \\
\text { H42 } \\
\text { J22 }\end{array}$ & $\begin{array}{l}4.86 \\
4.61 \\
4.28\end{array}$ & $\begin{array}{l}0.33 \\
0.36 \\
0.36\end{array}$ & $\begin{array}{l}0.97 \\
1.01 \\
1.08\end{array}$ & $\begin{array}{l}2.79 \\
2.86 \\
2.91\end{array}$ & $\begin{array}{l}0.114 \\
0.120 \\
0.117\end{array}$ \\
\hline $\begin{array}{l}\text { Urea, superphosphate, sulfate of potash, manure, } \\
\text { cover crop. } \ldots \ldots \ldots \ldots \ldots \ldots \ldots \ldots \ldots \ldots \ldots \ldots\end{array}$ & $\begin{array}{l}\text { M30 } \\
\text { E8 } \\
\text { H50 }\end{array}$ & $\begin{array}{l}4.60 \\
4.73 \\
4.29\end{array}$ & $\begin{array}{l}0.31 \\
0.28 \\
0.33\end{array}$ & $\begin{array}{l}1.86 \\
1.83 \\
1.89\end{array}$ & $\begin{array}{l}2.73 \\
2.72 \\
3.00\end{array}$ & $\begin{array}{l}0.124 \\
0.112 \\
0.130\end{array}$ \\
\hline
\end{tabular}

* Each sample was a composite from the eight trees of the fertilizer plot and consisted of about 160 leaves. Leaves were taken from spring-cycle fruit-bearing twigs in a band around the circumference of the tree. Sample collected in September 1945 .

as definite information is available, the direction in which values for each of the other nutrient elements changes when a given element is deficient. For example : If, under complete analysis, the value for potassium in orange leaves three to seven months old is less than 0.35 per cent, then it is likely that nitrogen will be somewhat higher than the average ( 2.45 per cent) commonly found in high-performance orchards ; calcium and magnesium are also almost certainly to be on the high side; while with respect to other constituents, not enough data are available to indicate the trend. 


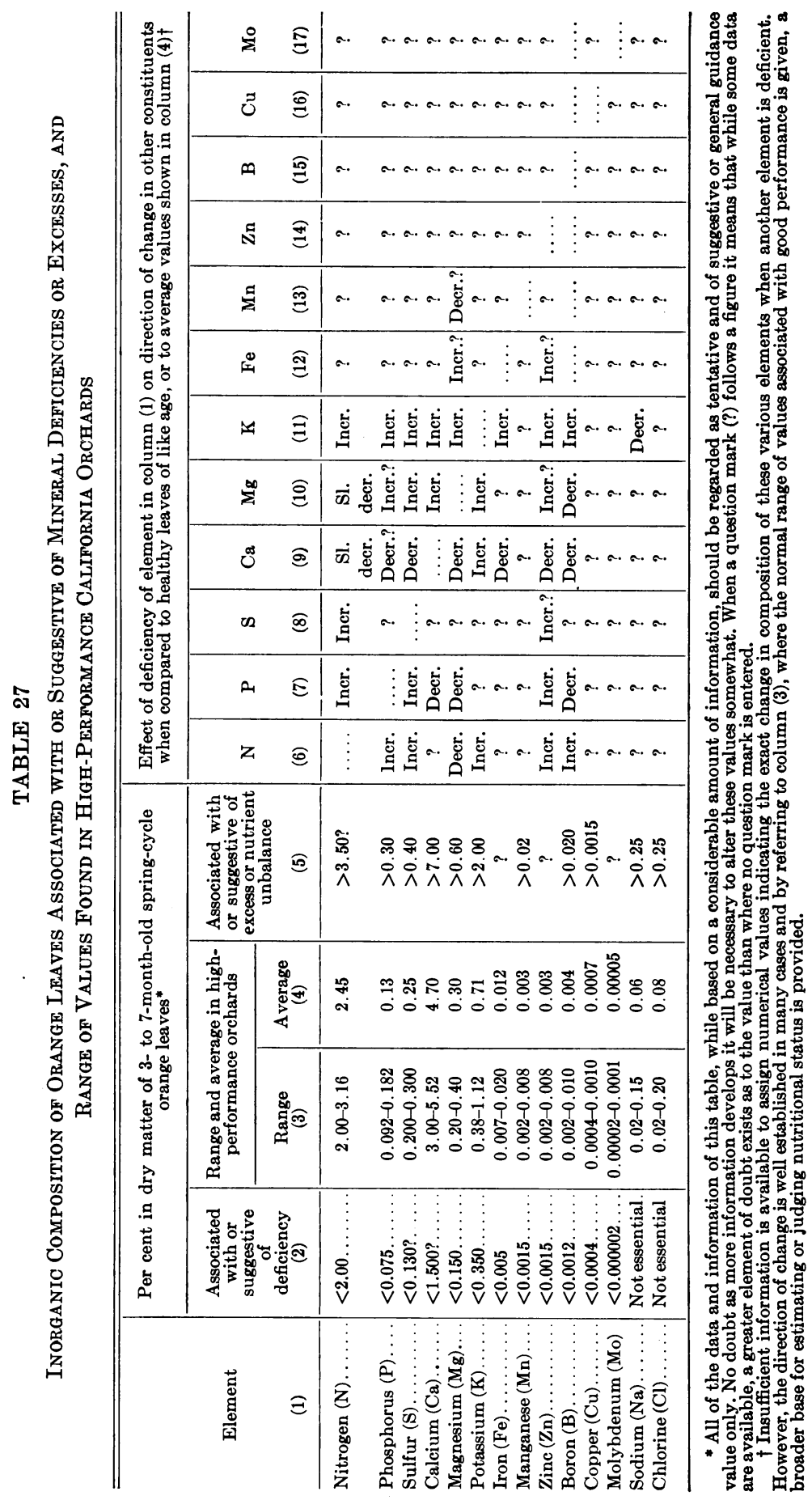




\section{SUMMARY}

A detailed investigation has been carried out to determine whether the potassium status of a citrus tree can be determined by leaf analysis. The study has shown that the leaf, of the various plant parts tested, best reflects the varying potassium condition of the nutrient medium. A set of standards based on controlled culture and field experiments has been worked out for three- to seven-month-old spring-cycle leaves, and is thought to reliably indicate the current potassium status of the tree. Detailed directions for sampling, analysis, and interpretation are given in the Appendix, pp. 536-37.

\section{ACKNOWLEDGMENTS}

The work reported in this paper was aided by a grant from the American Potash Institute. The authors wish to express their thanks and appreciation for this support.

The University of California Citrus Experiment Station fertilizer trials, initiated under the general direction of L. D. Batchelor and E. R. Parker and carried on in recent years under the latter's direction, have provided valuable material for this study. In addition, the rootstock plots initiated by the late H. J. Webber and carried on by L. D. Batchelor, have also provided important plant material for this study. The authors wish to thank these investigators for permission to draw on the experiments for plant and soil material. 


\section{APPENDIX}

\section{RECOMMENDED PROCEDURE FOR DETERMINING POTASSIUM STATUS OF ORANGE TREES BY LEAF ANALYSIS}

Based on the studies reported herein, it is believed that the potassium status of orange trees can be reliably assessed by leaf analysis. Directions for sampling, analysis, and evaluation follow.

A preliminary survey to determine orchard uniformity should be made. If tree condition varies distinctly in different parts of the orchard, composite leaf samples should be drawn from each area. In orchards which appear uniform it will probably suffice to take one composite sample from a representative part of the orchard. The choice of ten representative trees in any given sampling location is recommended. Twenty to 25 spring-cycle leaves from fruit-bearing twigs should be collected from each of the ten trees and composited into one sample. Leaves should be collected in a band around the circumference of the tree from positions near to the ground to as high as one can reach, the object being to obtain leaves representative both in size and condition of the average of this leaf-type on the tree. On fruit-bearing twigs the number of spring-cycle leaves will vary all the way from one to six or sevēn. Our practice has been to take only one leaf per twig, and, where there are several leaves, one more or less average in size. Position on the stem is immaterial, but the leaf must be spring-cycle. In some cases no spring-cycle leaves will be found on fruit-bearing twigs.

The fresh composite leaf sample is cleaned by wiping each leaf on both sides with dampened clean diaper or cheesecloth. Where minor elements are also to be determined, each leaf is dipped into an Ivory soap solution, rubbed with the fingers, the soap solution is rinsed off with tapwater and the leaf finally rinsed with distilled water. If the leaves are fresh, any one of several cleaning techniques may be used in determining potassium; the wiping technique is preferable if the leaves have partially dried out. The cleaned leaves are then placed in a container and dried in an oven at $50^{\circ} \mathrm{C}$ for 24 to 48 hours, or as long as is necessary to enable grinding. The leaves are then ground (if minor elements are to be determined, shattered by hand) and stored in stoppered bottles. Analyses for potassium are made by the cobaltinitrite method as follows :

Weigh out a 2-gm. sample of the ground leaf material and at the same time a 2-gm. sample for moisture determination. (Dry sample for 5 hours at $105^{\circ} \mathrm{C}$ for determination of moisture loss.) Ash the sample for analysis in a silica dish in a muffle furnace at $900^{\circ} \mathrm{F}$ until the ash is nearly white. After ignition, and when the dish is cold, carefully add $20 \mathrm{ml}$. cold distilled water. Cover with a watch glass and add $1 \mathrm{ml}$. concentrated nitric acid. When the reaction ceases, wash the spray on the watch glass into the silica dish and evaporate the contents to dryness on a steam bath. Treat the residue with 10 drops concentrated nitric acid and about $25 \mathrm{ml}$. hot water, and digest a few minutes on the steam bath. Filter and wash residue; collect filtrate in a 200 $\mathrm{ml}$. volumetric flask and make to volume. Pipette $10 \mathrm{ml}$. of the solution into a $30 \mathrm{ml}$. beaker and evaporate to dryness. Take up residue with $1 \mathrm{ml} .1 \mathrm{~N}$ nitric acid and $10 \mathrm{ml}$. distilled water. Add $5 \mathrm{ml}$. sodium cobaltinitrite solu- 
tion. (This reagent consists of $1 \mathrm{gm}$. trisodium cobaltinitrite salt in $5 \mathrm{ml}$. water. It should be made fresh prior to use and filtered.) Mix and allow to stand for 2 hours at room temperature. Filter in tared porous-bottom porcelain crucible, wash precipitate 10 times with $2 \mathrm{ml}$. portions of $0.011 \mathrm{~N}$ nitric acid and 5 times with $2 \mathrm{ml}$. portions of 95 per cent ethyl alcohol. Dry for 1 hour at $110^{\circ} \mathrm{C}$, cool in a desiccator, and weigh. $\mathrm{K}=17.216$ per cent of the weight of the precipitate. Calculate percentage potassium in the moisture-free sample.

Standards for evaluating potassium status are given in table 17 (page 525). Tentative standards for evaluating other nutrients are given in table 27 (page 534). 
ARNot, R. H.

\section{LITERATURE CITED}

1947. Potassium deficiency in coastal soils: A cause of decline in citrus and passion fruit. Agr. Gaz. New South Wales $58: 72-74$.

Batchelor, L. D., E. R. Parker, and Robert McBride.

1928. Studies preliminary to the establishment of a series of fertilizer trials in a bearing citrus grove. California Agr. Exp. Sta. Bul. 451:1-49.

Bathurst, A. C.

1943. New method for estimating the fertilizer requirements of citrus trees. Farming in South Africa 18:323-327.

1944. Leaf analysis of citrus. Farming in South Africa 19:325-330.

BRYAN, O. C.

1940. Malnutrition symptoms with citrus and practical methods of treatment. State of Florida, Dept. of Agr. No. 93, New Series.

CAMP, A. F., and B. R. FudGe.

1939. Some symptoms of citrus malnutrition in Florida. Florida Agr. Exp. Sta. Bul. 335.

Camp, A. F., H. D. Chapman, George M. Bahrt, and E. R. Parker.

1941. Symptoms of citrus malnutrition. Chapter IX, Hunger Signs in Crops. Published by The American Society of Agronomy and the National Fertilizer Assoc., Washington, D.C.

Chapman, H. D., and S. M. Brown.

1941. The effects of phosphorus deficiency on citrus. Hilgardia 14:161-182.

1941. The effects of sulfur deficiency on citrus. Hilgardia 14:185-202.

1943. Potash in relation to citrus nutrition. Soil Sci. 55:87-100.

Chapman, Homer Dwight, and Walter Pearson Kelley.

1943. The mineral nutrition of citrus. Chapter VII. The Citrus Industry, vol. I. Edited by Herbert John Webber and Leon Dexter Batchelor. University of California Press, Berkeley and Los Angeles.

Chapman, H. D.

1946. What we know and don't know about diagnosis of nutrient deficiencies and excesses of citrus. California Citrog. 31(11):416, 417 .

Chapman, H. D., f. M. Brown, and D. S. RaYNer.

1947. Effects of potash deficiency and excess on orange trees. Hilgardia 17:619-648.

FUDGE, B. R.

1939. Relation of magnesium deficiency in grapefruit leaves to yield and chemical composition of fruit. Florida Agr. Exp. Sta. Tech. Bul. 331.

Goodall, D. W., and F. G. Gregory.

1947. Chemical composition of plants as an index of their nutritional status. Imperial Bureau of Horticulture and Plantation Crops Tech. Communication No. 17, East Malling, Kent, England.

HAAS, A. R. C.

1937. Potassium in citrus leaves and fruits. California Citrog. February, 1937, pp. 154, 156.

1948. Magnesium deficiency and its effect on citrus. California Citrog. 33:134, 146, 150.

Hardy, F., J. C. McDonald, and G. Rodriguez.

1935. Leaf analysis as a means of diagnosing nutrient requirements of tropical orchard crops. Jour. Agr. Sci. 25:610-627.

INNES, R. F.

1946. Fertilizer experiments on grapefruit in Jamaica. Tropical Agriculture Trinidad $23: 131-134$. 
Kelley, W. P., and A. B. Cummins.

1920. Composition of normal and mottled citrus leaves. Jour. Agr. Res. 20:161-191.

LORENZ, O. A.

1942. Internal breakdown of table beets. Memoir Cornell Agr. Exp. Sta. 246:1-42.

MACY, $P$.

1936. The quantitative mineral nutrient requirements of plants. Plant Physiol. 11:749764.

OPPENHEIMER, H. R., and K. MENDEL.

1938. Problems of citrus nutrition II. Studies on the potash requirements of sweet lime. Hadar 11:177-181, 244-249.

OPPENHEIMER, H. $R$.

1945. Leaf analysis of Shamouti oranges. Palestine Jour. Bot. Rehovot Series, vol. 5(1): 86-95.

PARker, E. R., and L. D. BATChelor.

1942. Effect of fertilizers on orange yields. California Agr. Exp. Sta. Bul. 673:1-39.

PARBERRY, N. H.

1935. Mineral constituents in relation to chlorosis of orange leaves. Soil Sci. 39:35-45.

REED, H. S., and A. R. C. HAAS.

1923. Effect of sodium chloride and calcium chloride upon growth and composition of young orange trees. California Agr. Exp. Sta. Tech. Paper No. 4.

1923a. Growth and composition of orange trees in sand and soil cultures. Jour. Agr. Res. 24:801-814.

$1923 b$. Studies on the effects of sodium, potassium, and calcium on young orange trees. California Agr. Exp. Sta. Tech. Paper No. 11.

Shear, C. B., H. L. Crane, and A. T. Mrers.

1948. Nutrient element balance: Application of the concept to the interpretation of foliar analysis. Proc. Amer. Soc. Hort. Sci. 51:319-326.

ULRICH, ALBERT.

1948. Plant analysis. Methods and interpretation of results. Chapter VI, Diagnostic techniques for soils and crops. Ed. Herminie Broedel Kitchen. American Potash Institute, Washington 6, D.C.

VAILE, R. S.

1922. Fertilizer experiments with citrus trees. California Agr. Exp. Sta. Bul. 345:465512.

WILCox, L. V.

1937. Determination of potassium by means of an aqueous solution of trisodium cobalt: nitrite in the presence of nitric acid. Ind. and Eng. Chem. Anal. Ed. 9:136-138. 


\section{CONTENTS}

Introduction . . . . . . . . . . . . . . . 501

Review of Literature . . . . . . . . . . . . 502

Experimental Procedure . . . . . . . . . . . 503

Results . . . . . . . . . . . . . . . . 504

Standardization . . . . . . . . . . . . . . 519

Studies of sampling technique . . . . . . . . . 526

Discussion . . . . . . . . . . . . . . . . 530

Summary . . . . . . . . . . . . . . . . 535

Acknowledgments . . . . . . . . . . . . . 535

Appendix: Recommended procedure for determining potassium status of orange trees by leaf analysis . . 536

Literature cited . . . . . . . . . . . . . . 538 
The journal Hilgardia is published at irregular intervals, in volumes of about 600 pages. The number of issues per volume varies.

Subscriptions are not sold. The periodical is sent as published only to libraries, or to institutions in foreign countries having publications to offer in exchange.

You may obtain a single copy of any issue free, as long as the supply lasts; please request by volume and issue number from:

\section{Publications Office \\ College of Agriculture \\ Berkeley 4, California}

The limit to nonresidents of California is 10 separate issues on a single order. A list of the issues still available will be sent on request.

In order that the information in our publications may be more intelligible, it is sometimes necessary to use trade names of products or equipment rather than complicated descriptive or chemical identifications. In so doing, it is unavoidable in some cases that similar products which are on the market under other trade names may not be cited. No endorsement of named products is intended nor is criticism implied of similar products which are not mentioned. 